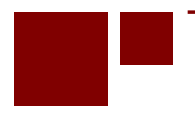

C E N T E R for RETIREMENT RE S E A R C H at BOSTON COLLEGE

\title{
DOES SOCIAL SECURITY CONTINUE TO FAVOR COUPLES?
}

\author{
Nadia S. Karamcheva, April Yanyuan Wu, and Alicia H. Munnell
}

CRR WP 2015-11

June 2015

\author{
Center for Retirement Research at Boston College \\ Hovey House \\ 140 Commonwealth Avenue \\ Chestnut Hill, MA 02467 \\ Tel: 617-552-1762 Fax: 617-552-0191 \\ http://crr.bc.edu
}

Nadia S. Karamcheva is an analyst at the Congressional Budget Office. April Yanyuan Wu is a researcher at Mathematica Policy Research. Alicia H. Munnell is the Peter F. Drucker Professor of Management Sciences at Boston College's Carroll School of Management and the director of the Center for Retirement Research at Boston College. The research reported herein was performed pursuant to a grant from the U.S. Social Security Administration (SSA) funded as part of the Retirement Research Consortium. The opinions and conclusions expressed are solely those of the authors and do not represent the opinions or policy of SSA, any agency of the federal government, the Congressional Budget Office, Mathematica Policy Research, or Boston College. Neither the United States Government nor any agency thereof, nor any of their employees, makes any warranty, express or implied, or assumes any legal liability or responsibility for the accuracy, completeness, or usefulness of the contents of this report. Reference herein to any specific commercial product, process or service by trade name, trademark, manufacturer, or otherwise does not necessarily constitute or imply endorsement, recommendation or favoring by the United States Government or any agency thereof.

(C) 2015, Nadia Karamcheva, April Yanyuan Wu, and Alicia H. Munnell. All rights reserved. Short sections of text, not to exceed two paragraphs, may be quoted without explicit permission provided that full credit, including $(\subset)$ notice, is given to the source. 


\begin{abstract}
About the Center for Retirement Research
The Center for Retirement Research at Boston College, part of a consortium that includes parallel centers at the University of Michigan and the National Bureau of Economic Research, was established in 1998 through a grant from the Social Security Administration. The Center's mission is to produce first-class research and forge a strong link between the academic community and decision-makers in the public and private sectors around an issue of critical importance to the nation's future. To achieve this mission, the Center sponsors a wide variety of research projects, transmits new findings to a broad audience, trains new scholars, and broadens access to valuable data sources.
\end{abstract}

Center for Retirement Research at Boston College

Hovey House

140 Commonwealth Ave

Chestnut Hill, MA 02467

Tel: 617-552-1762 Fax: 617-552-0191

http://crr.bc.edu

Affiliated Institutions:

The Brookings Institution

Massachusetts Institute of Technology

Syracuse University

Urban Institute 


\begin{abstract}
While dramatic increases in women's labor supply and earnings have led to a substantial decline in the fraction of women eligible for spouse benefits at retirement, most wives still receive a survivor benefit, as wives still typically have lower earnings than their husbands and live longer. Using the MINT microsimulation model and the HRS data linked with Social Security administrative earnings records, this paper examines the extent to which Social Security continues to favor couples and will do so in the future.
\end{abstract}

The paper found that:

- While the Old-Age and Survivors Insurance program still distributes lifetime income from singles to couples, the transfers appear to be shrinking over time.

- Nevertheless, couples are still projected to have a higher benefit/tax ratio, a lower median net tax rate, and a greater likelihood of receiving positive net transfers from the system compared to those who are never married or divorced.

- The increased labor force participation and earnings of women have contributed significantly to the decline in redistribution from men to women, and from singles to couples, while the effect of declining marriage rates has only a modest effect.

The policy implications of the findings are:

- Family benefit provisions within the Social Security program can have a significant impact on various measures of redistribution.

- Policymakers may find the results of this paper helpful in evaluating any reform proposals that would change these provisions. 


\section{Introduction}

Introduced into the Social Security program in 1939, spouse and survivor benefits have important implications for the retirement security of women. At the same time, the extent to which these family benefits impact "horizontal equity" of the Social Security program has been a consistent interest in academic circles and the broader policy community.

Spouse and survivor benefits were established at a time when most households consisted of a single earner, typically the husband. The provisions of these benefits were intended to increase adequacy, particularly important for women with little or no lifetime earnings. On virtually every dimension, women’s economic lives have changed, and these changes are remaking the current and future profile of the U.S. retiree population. Compared to 30 years ago, married women today have higher levels of education, increased labor force participation, more stable career trajectories, and higher salaries. Wu et al. (2013) examined how women's changing lives have affected the Social Security replacement rates that individuals and households receive at the time of first claiming. Their study found that Social Security replacement rates have dropped sharply at both the household and individual levels, and the declines will continue for future retirees. The decline in replacement rates over time is largest for married couples in which husbands have higher earnings.

However, analyzing replacement rates only at the time of initial claiming does not allow examination of how Social Security redistributes income on a lifetime basis; moreover, it misses an important aspect of the relationship between family structure and Social Security benefits. While an extensive literature has documented a substantial decline in the fraction of women eligible for spousal benefits at retirement, Butrica and Smith (2012) find that most wives would still receive a survivor benefit, as wives still typically have lower earnings than their husbands and live longer. Thus, on a lifetime basis, the extent to which benefits per dollar of contributions for couples relative to single earners has changed is unclear.

This paper examines the extent to which Social Security continues to favor couples and will do so in the future. It explores changes in the ratio of the expected present value of Social Security benefits to the expected present value of contributions by marital status at both the household and individual level over time and for future retirees. The primary analysis is based on the Modeling Income in the Near Term (MINT) microsimulation model. We also supplement MINT with the Health and Retirement Study (HRS) linked with Social Security administrative 
earnings records, which contain lifetime earnings profiles of actual workers and provides details of workers' demographics and marital status. The paper extends previous studies by making use of rich data sources to produce the measures of redistribution across a broad range of cohorts: from the Depression Era (born 1931-41) to Generation X (1966-75). This paper focuses on several measures of redistribution: 1) the ratio of the expected present value of Social Security benefits to the expected present value of contributions; 2) the lifetime net tax rate, defined as the present value of lifetime Old-Age and Survivors Insurance (OASI) tax payments minus the present value of lifetime OASI benefits divided by the present value of the individual's lifetime earnings; and 3) the share of individuals with a negative tax rate or, in other words, the share receiving positive transfers from Social Security.

The results show that while the OASI program still distributes lifetime income from men to women, and from singles to couples, the transfers appear to be shrinking over time.

Nevertheless, couples - particularly single-earner households of the Gen X population - are still projected to have a higher benefit/tax ratio, a lower median net tax rate, and a greater likelihood of receiving positive net transfers from the system than those who are never married or divorced. The decomposition analysis shows that the increased labor force participation and earnings of women have contributed significantly to the decline in redistribution from men to women, and from singles to couples. Differences in marital status have effects that are statistically significant but economically small in explaining the total difference.

The paper is arranged in eight sections, beginning with this introduction. The second section provides background information on the Social Security program, discusses how women's roles have changed over time, and presents a brief overview of prior studies. The third section describes the datasets and the methodology. The fourth section discusses measures of redistribution. The fifth section summarizes changes in redistribution across cohorts and within cohorts by marital status and income. The sixth section discusses the decomposition procedure used to investigate how the changing roles of women - characterized by both labor force activity and marital patterns - explain the differences in redistribution across cohorts. The seventh section describes the sensitivity tests and the final section concludes. 


\section{Background}

\section{Social Security Program}

Social Security benefits are programmatically linked to both earnings and marital histories. Social Security pays retired-worker benefits to individuals who have accumulated 40 or more quarters of earnings in covered employment over their lives. Benefits at the Full Retirement Age (FRA) are the result of a three-step process. First, a worker's previous earnings are restated in terms of today's wages by indexing past earnings up to age 60 to wage growth. Second, indexed earnings for the highest 35 years are then averaged and divided by 12 to calculate Average Indexed Monthly Earnings (AIME). The final step is to calculate the Primary Insurance Amount (PIA), which is the sum of applying three separate percentages to portions of the AIME. The portions are determined by earnings thresholds - or "bend points" - that are indexed to wage growth, and thus depend on the year in which a person reaches age 62 . Specifically, for workers first becoming eligible for benefits in 2014, their PIA is the sum of:

- 90 percent of the worker's first $\$ 816$ of AIME, plus

- 32 percent of AIME between $\$ 916$ and $\$ 4,917$, plus

- 15 percent of any AIME in excess of \$4,917.

This PIA is recalculated as long as the individual remains employed; it is indexed to prices from age 62. The benefit actually paid depends on when the worker claims. Benefits paid between age 62 and the FRA are actuarially reduced, and benefits paid between the FRA and 70 are actuarially increased.

In addition to the worker's benefit, Social Security provides dependent benefits to qualified spouses of retired workers. While these benefits are not gender based, they typically go to women because women tend to work less and earn less than men. Thus, a wife is entitled to two types of benefits: 1) a spouse's benefit that will top up her own retirement benefit to 50 percent of her husband's PIA (unreduced for his early retirement); and 2) a survivor's benefit that will top up her own benefit to 100 percent of her husband's benefit (reduced for early retirement). Dependent divorced spouses are entitled to benefits if their marriage lasted at least 10 years. A person with a previous marriage that ended in widowhood is also eligible if the deceased spouse was fully insured. 
Women's Changing Life and the Social Security Program

On virtually every dimension, women's economic and social characteristics have changed, and these changes are remaking the current and future profile of the U.S. retiree population. As women's labor force participation and earnings increase, more and more female retirees will receive benefits based on their own working record, and fewer of them will be eligible for only auxiliary benefits, based on their husbands' working history. Wu et al. (2013) reported that only 37 percent of the 24 to 35 year-old women in the Depression Era 1 (19311935) cohort worked, compared with 73 percent of their counterparts, born 35 years later - Gen $\mathrm{X}$ (1966-1975). The increase in the propensity to work is particularly pronounced among married women. On the other hand, marriage rates have fallen sharply. While almost 70 percent of women close to retirement age (55-64) in the oldest cohort were married, the proportion is projected to decline to 56 percent for those born in the late '60s (Wu et al. 2013).

These trends are significantly changing the nature of women's benefit eligibility (Figure 1). The share of women receiving benefits based on their own work history is projected to jump from 44 to 75 percent between the oldest and youngest cohorts. Another 18 percent of women in the Gen X cohort will be dually entitled - they will have gained 40 quarters of covered earnings and be eligible for their own benefit, but still receive a spousal "top-up.” Only 7 percent of Gen $\mathrm{X}$ women will have to rely on only auxiliary benefits, three times fewer than the women born in the 1930s (25 percent). On the other hand, our analysis also shows that the share of women receiving higher benefits as a survivor declines over time from 84 percent for the DE1 cohort to only 68 percent for the Gen Xers (Figure 2).

\section{Literature to Date}

Although an extensive literature has examined the progressivity of the Social Security program (Coe et al. 2014; Brown, Coronado, and Fullerton 2009; Liebman 2002; Gustman and Steinmeier 2001; Cohen, Steuerle, and Carasso 2001; Coronado, Fullerton, and Glass 2000), only a few studies have focused on the implications of the changing role of women.

Smith, Toder and Iams (2003) examine the lifetime distribution of actual and projected net benefits (benefits minus payroll taxes) from the OASI program for people born between 1931 and 1960, using the MINT simulation model. They find that the growing share of women receiving worker benefits instead of spouse or survivor benefits, plus the increased proportion of 
retirees who are divorced, make OASI benefits more progressive, even in the face of declining net benefits.

Butrica and Smith (2012) explore the impact of women's increasing labor force participation and earnings on married women's Social Security benefits and find that the share of married women projected to receive spouses' benefits at retirement has declined in more recent birth cohorts. Although most wives will still be eligible for survivor benefits, the share ineligible is projected to double between cohorts. Using the Current Population Survey (CPS), Munnell, Sanzenbacher, and Soto (2007) directly evaluate the impact of increased labor force participation of wives on the Social Security replacement rate of couples and find that, over the last forty years, the replacement rate for the average couple has declined from 50 percent to 45 percent.

In Wu et al. (2013), we examined how women’s changing lives have affected the Social Security replacement rates - the ratio of initial benefits to AIME - that individuals and households receive at first claiming. Studying the same range of cohorts, we showed a marked decrease over time in the proportion of pre-retirement income that Social Security replaces at the time of first claiming. However, analyzing replacement rates only at initial claiming has two disadvantages: first it does not allow examination of how Social Security redistributes income on a lifetime basis; and second, it misses an important aspect of the relationship between family structure and Social Security benefits. Despite women's rising labor force attachment, most wives' lifetime earnings will still be lower than their husbands', making them eligible to receive higher survivor benefits based on their husbands’ record. Never married individuals or those who are divorced with a longest marriage lasting less than 10 years will not have this option. Studying the benefits and contributions from Social Security on a lifetime basis, rather than at a point in time, allows us to better assess the redistributive power of the system and examine whether Social Security continues to favor couples.

The following analysis, which builds on the existing literature, has two goals. The first is to investigate how Social Security redistribution changed across a broad range of cohorts and within cohorts by marital status. The second goal is to explain the extent to which the changing lives of women can explain the changes in the system's redistribution patterns. 


\section{Data and Methodology}

For the primary analysis, the data come from Modeling Income in the Near Term (MINT), a microsimulation model developed by the Social Security Administration (SSA). MINT links individuals' demographic information and marital histories from the Survey of Income and Program Participation (SIPP) with their earnings and benefit histories from SSA administrative data. Based on these data, MINT projects each retiree's income from Social Security benefits, pensions, assets, and earnings (for working beneficiaries). ${ }^{1}$ Our MINT sample covers a broad range of birth cohorts: Depression Era (born 1931-41), War Baby (1942-47), Early Baby Boomers (1948-53), Middle Baby Boomers (1954-59), Late Baby Boomers (196065), and Generation X (1966-75). ${ }^{2}$ The major advantage of using MINT is to project the changes in the benefit per dollar of contribution for future retirees, cohorts where female labor force participation and marital patterns have changed most dramatically.

We also supplement the MINT analysis with analysis using the HRS data matched to the Social Security administrative earnings records. The HRS is a nationally representative longitudinal study of older Americans. The survey began in 1992 with an initial cohort of 12,652 individuals from 7,607 households in which at least one member was born between 1931 and 1941. Additional cohorts were added later. Individuals may opt to have their Social Security earnings histories linked to their survey, and approximately 70 percent of respondents have done so. Our HRS sample is grouped into three birth cohorts: Original HRS (1931-1941), War Baby (WB, 1942-1947), and Early Baby Boomers (EBB, 1948-1953). ${ }^{3}$ The HRS contains lifetime earnings profiles of actual workers and provides details of workers' demographics and marital status. Using the HRS provides an external comparison to our MINT estimates.

\footnotetext{
${ }^{1}$ For descriptions of versions 5 and 6 of MINT, see Smith et al. (2007, 2010, respectively).

${ }^{2}$ To ensure that our cohort estimates are representative, and to minimize survival bias, we use two versions of the MINT model - MINT 5 and MINT 6. Statistics related to the HRS (1931-1935) cohort in our analysis are derived from MINT 5, while the rest of the cohorts are extracted from MINT 6. MINT6 uses data from SIPP panels 20012004 matched with SSA administrative records through 2008, while MINT5 is based on 1990-1996 panels of SIPP with SSA administrative records through 2001.

${ }^{3}$ We did not include the Children of the Depression Era (CODA), born in the late 1920s. When we first observed individuals of the CODA cohort in 1998, they were 68-74 years old and about 40 percent were widowed. Because of the selection bias due to mortality, the replacement rate calculated using the HRS for the CODA cohort does not represent the replacement rate of all individuals born during this period. Further, for the majority of widows (widowers) of the CODA cohort, we do not have the information on their late spouses. Thus, we decided to exclude the CODA cohort from our analysis.
} 


\section{Lifetime Earnings}

Lifetime earnings serve as a base for calculating Social Security taxes paid and benefits entitled. MINT projects each person's mortality, entry to and exit from Social Security Disability Insurance rolls, and age of first receipt of Social Security retirement benefits. For younger cohorts, MINT projects their income and characteristics into the future, adjusting for expected demographic and socioeconomic changes. Further, MINT accounts for major changes in the growth of economy-wide real earnings, the distribution of earnings both between and within birth cohorts, and the composition of the retiree population. Since MINT is designed to simulate the whole earnings profile, no additional simulation is needed.

In the HRS, the administrative data provide Social Security earnings histories back to 1951 for the approximately 70 percent of the sample that has given permission to link. While previous work has documented that giving permission to link is nonrandom (Haider and Solon 2000), the distribution of Social Security benefits is similar across the linked and non-linked respondents (Kapteyn et al. 2006). Thus, for the approximately 30 percent of the HRS sample that has not given permission to link, we follow Gustman and Steinmeier (2001) and estimate earnings histories based on survey data on previous jobs and wages, using the estimated returns to tenure from Anderson, Gustman, and Steinmeier (1999). ${ }^{4}$

For the HRS analysis, the actual claiming age is used if respondents have already claimed Social Security benefits. For those yet to claim, we assume that respondents claim Social Security benefits at their self-reported expected retirement age. ${ }^{5}$ Combining the actual earnings with the simulated earnings yields a complete earnings profile for each individual in the HRS sample from 1951 to retirement age. The mortality assumptions embedded in the HRS calculations start with mortality tables from the SSA, which have data by age and gender. These tables are then adjusted, based on the results of Brown, Liebman and Pollet (2002), to reflect the fact that survival probabilities vary with education and race.

\footnotetext{
${ }^{4}$ To project earnings beyond the year at which the individual last gave permission to match to the administrative data, we again follow Gustman and Steinmeier (2001). For individuals with self-reported earnings, the assumption is that the average of their real earnings observed in the last three reported periods persists until their expected claiming date.

${ }^{5}$ If the expected retirement age was greater than 70, or if the individual indicated that he never expected to retire, a retirement age of 70 is used unless the individual had already worked beyond that age. If the respondent did not provide an expected retirement age, we assign them a claiming age so that the age distribution of claiming matches the Social Security reported claiming ages (U.S. Social Security Administration 2010, Table 6.B5.1).
} 


\section{Social Security Benefits}

The Social Security PIA is calculated by applying a piecewise-linear formula to each worker's AIME. In computing the AIME using MINT, earnings prior to age 60 are indexed by the average wage index for the year the individual attains age $60 .{ }^{6}$ Earnings after age 60 are not indexed. AIME is the monthly average of the indexed earnings in the 35 highest-earnings years. A retiree is entitled to a benefit equal to the PIA at the FRA. A worker may choose to retire as early as age 62, with reduced benefits. If a worker delays receipt of benefits to an age as late as 70, the eventual benefits are permanently increased for each year of delay.

Current marital status and marital history are important in determining spousal or survivor benefits. MINT observes marriage patterns in the periods covered in the SIPP panels when husbands and wives can be precisely identified. For individuals projected to change marital status after the last SIPP observation (or whose former spouses from before the SIPP panel are not observed), the model statistically matches married individuals with a spouse with characteristics of a likely match. The spousal and survivor benefits then are calculated using these observed and imputed spouses. For the purpose of calculating lifetime measures, the household's relevant marital status as of age 62 is taken.

The calculation of benefits is done in an analogous way using data from the HRS. For those who have claimed Social Security, benefit eligibility type is determined by the relevant marital status at the time of benefit claiming and, for those who have not, it is determined at the last wave in which we observe them in the survey and we assume the last reported marital status does not change before claiming the benefits. If divorced with a previous marriage that lasted 10 or more years, we first determine if the ex-spouse is in the sample. If the ex-spouse is not in the sample, we match the respondent to someone else in the survey by gender, education, race, and 5-year birth year band. We then use the earnings histories of the matched spouse to compute the spousal and survivor benefit available from the ex-spouse. For the widows (widowers) whose deceased spouses are missing from the sample, we match the respondents with another widow(er) in the sample, based on gender, race, education, 5-year birth cohort, and retirement

\footnotetext{
${ }^{6}$ Our lifetime measures of benefits and taxes are calculated as of age 62. When the analysis is done on a household basis, we average the lifetime benefits, taxes and earnings of the married couples by summing and then dividing by two. When the spouses are of different ages, the measures are brought in real terms to the year when the younger spouse reaches age 62, and then averaged.
} 
age. We then use the earnings histories of that person's deceased spouse to estimate survivor benefits.

\section{Social Security Taxes}

The earnings profiles serve as a base for estimating Social Security taxes paid, based on the schedules in place at the time the wages were earned. Currently workers pay direct OASI contributions equal to 5.3 percent of their covered earnings up to a taxable maximum of $\$ 117,000$. Employers also make contributions equal to 5.3 percent of covered earnings. Even though the employee and the employer each pay half the tax, theory and research (Hamermesh and Rees 1993, Piketty and Saez 2007) suggest that the worker bears the full burden.

While the total taxation for the OASI and Disability Insurance (DI) programs is 6.2 percent, we only focus on the 5.3-percent portion in order to be consistent with previous studies and examine the OASI system separately. Thus we also exclude from the sample individuals who are projected to receive DI benefits, which allows us to create comparable measures of lifetime OASI benefits and contributions.

\section{Unit of Analysis}

The results differ substantially depending on whether the unit of analysis is the individual or the household, which is driven by the fact that many of the spousal and survivor benefits flow to individuals who would appear as low earners but in fact might be spouses of high earners. We present results both on individual and household levels.

\section{Discount Rates}

When calculating present values, we initially use a discount rate of 2.9 percent, which is consistent with the Social Security actuaries' intermediate real interest rate projection. However, we conduct sensitivity analysis using a real interest rate of 2.0 percent, which has been used in previous literature (see for example Brown, Coronado, and Fullerton 2009), and a discount rate that reflects the historic return on long-term Treasury bonds. Caldwell et al. (1999) argue that the return should reflect the risk that individuals would face on investments in assets with 
comparable risk. More recent papers have used the 10-year U.S. government bond rate as a discount factor in calculating Social Security benefits and returns (e.g., Coe et al. 2011). ${ }^{7}$

\section{Measures of Redistribution}

We examine the following several measures of redistribution: 1) the benefit/tax ratio - the ratio of the present value of Social Security benefits to the present value of contributions; 2) the lifetime net tax rate, defined as the present value of lifetime OASI tax payments minus the present value of lifetime OASI benefits divided by the present value of the individual's lifetime earnings; and 3) the share of individuals with a negative tax rate or, in other words, the share receiving positive transfers from Social Security. ${ }^{8}$

\section{The Ratio of Lifetime Benefits to Lifetime Contributions (Benefit/Tax Ratio)}

Armed with earnings histories, tax payments, projected benefits, and a discount rate, the study estimates the ratio of the expected present value of Social Security benefits to the expected present value of contributions at both the household and individual level across seven birth cohorts by marital status. The ratio is calculated at age 62. At the household level, for married households, the ratio is calculated as the sum of the present value of the benefits of both husband and wife to the sum of the present value of the taxes paid by the couple. ${ }^{9}$ In the case of individuals who find themselves widowed or divorced at the time they first start receiving benefits, we create a lifetime shared taxes measure, which equals the individual's taxes paid in years when he was not married and one half the taxes paid by the couple in years in which he was married. Thus, the ratio for widowed and divorced persons is the ratio of the present value of the Social Security benefit that the widow(er)/divorcee receives to the present value of the shared lifetime taxes paid. Divorced individuals whose longest marriage lasted for less than 10 years are treated the same way as never married individuals. At the individual level, the ratio is

\footnotetext{
${ }^{7}$ We use the 10-year T-Bill rate till 2011 and SSA's intermediate interest rate projection after 2011.

${ }^{8}$ We chose not to use internal rates of return (IRRs) as a measure, since previous authors have indicated that it can be problematic. For example, Coe et al. (2011) point out that in this context the values of different income streams cannot be ranked according to the magnitudes of their IRRs.

${ }^{9}$ Measures are calculated at age 62 for individuals and at the age when the younger spouse reaches 62 for couples. When the spouses are of different ages, the individual present values, after being calculated in the year when each spouse reaches age 62, and before the household ratio is calculated, are brought in real terms to the year when the younger spouse reaches 62 .
} 
calculated as the ratio of the present value of the individual's benefits (can be spouse/survivor or retired worker benefit) to his/her own taxes paid. ${ }^{10}$

\section{Net Tax Rate and Share Receiving Positive Transfers}

Following previous literature, we define the net tax rate as the present value of lifetime OASI tax payments minus the present value of lifetime OASI benefits divided by the present value of lifetime total earnings. Besides the median net tax rates, we also report the share of the population with negative tax rates, indicating that they are receiving a net transfer from Social Security.

\section{Changes in Redistribution over Time}

\section{Changes at Individual Level}

Table 1 provides a close look at the demographics of the MINT sample at the time of initial claiming of Social Security benefits. As expected, we see a declining share of individuals who enter retirement as a married couple, and instead a more than two-fold increase between the oldest and youngest cohort in the share who are divorced, and a three-fold increase in the share who are never married. Educational attainment is rising over time and so is the labor force participation of women, especially married women. Married women in the DE1 cohort had accumulated on average 75 quarters of covered earnings by the time they started their Social Security benefits, compared with 120 quarters of coverage for their counterparts in the Gen X cohort. Years of coverage have increased also for the widowed, divorced, and never married women in this order, although to a smaller degree.

Figures 3, 4, and 5 show the trends of individual benefit/tax ratios for the whole range of cohorts in our analysis by marital status and gender. The results illustrate a decline in the overall generosity of the system as seen in the declining median benefit/tax ratios for all groups over time. The median benefit/tax ratio declined from 1.41 for the individuals of the DE1 cohort to 1.11 for individuals of the Gen X cohort (Figure 3). This aggregate trend masks more complex patterns by gender and marital status. While overall, women receive more in benefits as a share of the taxes they paid as compared with men, they also experience higher declines in their benefit/tax ratios as compared to men (Figures 4 and 5). The decline is steepest for women who

\footnotetext{
${ }^{10}$ For individuals who do not have positive lifetime earnings, the ratio is undefined.
} 
enter retirement married, or widowed, while never married women see their benefit/tax ratios declining only slightly. Within all cohorts, however, the median woman is projected to receive a benefit/tax ratio of more than one, indicating that on a lifetime basis the typical woman receives more from the OASI program in benefits than she contributes in OASI taxes. The pattern varies significantly across marital status, with the typical widowed woman having the highest benefit/tax ratio, followed by those who are married, divorced, and never married.

In contrast, the individual benefit/tax ratios for men are projected to decline only slightly for future cohorts, and the ratio is relatively constant across marital status. Starting with the EBB cohort, on an individual basis, men are projected to have a median benefit/tax ratio of less than 1 , which remains relatively flat with time. Among the Gen Xers, never married men have the highest benefit/tax ratio, followed by men who are married, then the widowed, and finally the divorced (0.95, 0.93, 0.88, 0.87 respectively).

Another interesting observation is that the never married men and women look much more similar to each other than the men and women of any of the other marital groups. While this was true among the DE1 cohort, it is even more so among the War Baby and later cohorts.

Figure 6 examines the changes in the median net tax rate on an individual basis, and records expected increases in the net tax rates of all marital groups, which is consistent with the earlier finding of declining benefit/tax ratios. While increasing, the median net tax rate remains negative for all groups and cohorts, indicating that at least half of the individuals in all groups are receiving positive net transfers from Social Security. The net tax rate has risen most dramatically for the widowed. Still, among the Gen Xers, on an individual basis the OASI program seems to distribute predominantly from never married and divorced individuals to those who are married, or widowed.

\section{Changes at Household Level}

On a household basis, benefit/tax ratios are projected to decline from 1.36 to 1.07 between the oldest and youngest cohorts. The decline is steepest for the widowed (48 percentage points), followed by married couples (27 percentage points), then the divorced (25 percentage points) and the never married (19 percentage points) (Figure 7). The decline is steeper for single-earner married households than for two-earner households (34 versus 23 percentage points). 
This surprising result reflects a change among single-earner households. Although in the majority of single-earner households the wife receives benefits based on the husband's earnings record, the share of such households is projected to drop sharply across cohorts - from 72 percent of EBBs to 64 percent for the Gen Xers (not shown). Instead, the share of single-earner households in which the spouses' benefits are based on the wife's earnings history is increasing. The latter category of households tend to have lower benefit/tax ratios as the typical husband who is not eligible for Social Security benefits based on his own record has usually worked for more years and contributed more in taxes (or to the denominator) than a comparable typical noneligible wife. $^{11}$

Figures 8 and 9 present the evolution of the other two measures of redistribution - the median net tax rate and the share receiving positive transfers from the system, by marital status. While the median net tax rate has risen for all groups, it is still projected to remain below 0 for those in the Gen $\mathrm{X}$ generation, suggesting that at least half of the households in each marital group are expected to receive positive transfers from the system (Figure 8). Figure 8 further shows a significant convergence over time in the median net tax rate among the never married, the married/two earners and the divorced, on one hand, and the widowed and married/single earners, on the other hand. A similar trend is observed in the proportion with positive transfers from the system (Figure 9). Overall, despite the convergence in the marital groups, examination of the three measures of redistribution shows that - even for those in the Gen X cohort - the system is expected to keep redistributing from the never married, divorced, and married/two earners to married/single earners and the widowed - although to a smaller degree compared with the DE1 cohort.

Figures 10, 11, and 12 further examine changes in the redistribution among married household types by the husband's earnings. As expected, both single- and two-earner couples with husbands in the bottom tercile of the earnings distribution have, on average, higher benefit/tax ratios, lower net tax rates, and are more likely to receive positive transfers from the system. Despite the overall decline in the returns from the program, couples in all cohorts with husbands in the bottom and middle of the earnings distribution have median benefit/tax ratios above 1 and more than half are receiving positive transfers. In contrast, starting with the EBB

\footnotetext{
${ }^{11}$ In a previous paper, using the same data we found that this result is also true when examining initial Social Security replacement rates, or those at the time of first claiming.
} 
cohort, the median benefit/tax ratio for all married couples with husbands' earnings in the top tercile falls below one. It is also interesting to note that, over time, single- and two-earner couples are starting to look more alike in their returns from the system. However, the gap is not fully closed and, among the Gen X population, single-earner households have a lower median net tax rate and are more likely to receive positive net transfers from the system than two-earner households, even within husbands' earnings terciles.

In summary, the analysis shows that while the OASI program still distributes lifetime income from men to women, and from singles to couples, the gap in the transfers from the system that different household types receive appears to be shrinking over time.

\section{Decomposing the Changes in Redistribution to Their Contributing Factors}

This section examines how much of the changes in the redistribution of the OASI program can be explained by the changing lives of women - labor force participation and marriage patterns - as opposed to other explanations.

\section{Conception Framework}

To examine the observable differences in lifetime contributions and benefits from Social Security across cohorts, we use two decomposition techniques. To examine mean differences in outcomes such as the propensity to receive net transfers from the system, we use a technique based on the work of Oaxaca (1973) and Blinder (1973), a decomposition method widely used in social science research. This method can be used to decompose the observable differences between the two groups into an explained and unexplained portion, which allows us to examine what one group's outcomes would have looked like if it had the characteristics of another group. It is also particularly useful for quantifying the separate contributions of various factors.

In the linear case, the two-fold decomposition is straightforward and can be obtained by least squares estimation on the two group-specific samples. Based on these estimates, the decomposition is computed as: ${ }^{12}$

\footnotetext{
${ }^{12}$ Assuming a linear model $Y_{k}=X_{k}^{\prime} \beta_{k}+e_{k}, k \in\{A, B\}$ and a mean zero error $E\left(e_{k}\right)=0$. An alternative two-fold decomposition is one in which a third vector $\beta^{*}$ of coefficients is used to determine the contribution of the differences in the predictors. The difference in mean outcomes can then be written as:

$\hat{R}=\left[\overline{X_{A}}-\overline{X_{B}}\right]^{\prime} \widehat{\beta^{*}}+\left[\overline{X_{B}}\left(\widehat{\beta_{A}}-\widehat{\beta^{*}}\right)+\overline{X_{A}}\left(\widehat{\beta^{*}}-\widehat{\beta_{B}}\right)\right]$, with the decomposition presented earlier being a special case where $\widehat{\beta^{*}}=\widehat{\beta_{A}}$. Neumark (1988) advocates the usage of the coefficients from the pooled regression over both
} 


$$
\widehat{R}=\overline{Y_{A}}-\overline{Y_{B}}=\left(\overline{X_{A}}-\overline{X_{B}}\right)^{\prime} \widehat{\beta_{A}}+{\overline{X_{B}}}^{\prime}\left(\widehat{\beta_{A}}-\widehat{\beta_{B}}\right)
$$

Equation (2) can be used in the aggregate to find what share of the total difference in the first moments can be attributed to differences in characteristics, and what share to differences in coefficients. Given the linearity of the model, it is also straightforward to find the contribution of each variable to the total difference, that is, the detailed decomposition. However, if the outcome is binary, such as whether an individual or household receives net transfers from Social Security, and the coefficients are derived from the probit or logit model, they cannot be used directly in equation (2) to derive the detailed decomposition. Instead we apply the non-linear decomposition techniques developed by Yun (2004).

Notice that a more general way to write equation (2) is:

$$
\hat{R}=\overline{Y_{A}}-\overline{Y_{B}}=\left[\overline{F\left(X_{A} \beta_{A}\right)}-\overline{F\left(X_{A} \beta_{B}\right)}\right]+\left[\overline{F\left(X_{B} \beta_{A}\right)}-\overline{F\left(X_{B} \beta_{B}\right)}\right](2)
$$

where $Y=F(X \beta)$ and the dependent variable is a function of a linear combination of independent variables, but the function $\mathrm{F}$ itself may not be linear. The Blinder-Oaxaca decomposition is a special case of equation (3). At the aggregate level, equation (3) can be used to calculate the total "explained" and "unexplained" portion as described above. To derive the detailed decomposition, however, one needs a method to properly weigh the contribution of each variable to the characteristics and coefficient effects. Using weights derived from a linearization of the decomposition equation, Yun (2004) develops a methodology for the detailed decomposition, which is free from path dependence and can be expressed as:

$$
\begin{aligned}
\overline{Y_{A}}-\overline{Y_{B}}=\sum_{i=1}^{M} W_{\Delta X}^{i}\left[\overline{F\left(X_{A} \beta_{A}\right)}-\overline{F\left(X_{A} \beta_{B}\right)}\right] \\
+W_{\Delta \beta}^{i} \sum_{i=1}^{M}\left[\overline{F\left(X_{B} \beta_{A}\right)}-\overline{F\left(X_{B} \beta_{B}\right)}\right] \text { (3) }
\end{aligned}
$$

where

$$
W_{\Delta X}^{i}=\frac{\left(\bar{X}_{A}^{i}-\bar{X}_{B}^{i}\right) \hat{\beta}_{A}^{i}}{\left(\bar{X}_{A}-\bar{X}_{B}\right) \widehat{\beta}_{A}} \text { and } W_{\Delta \beta}^{i}=\frac{\bar{X}_{B}^{i}\left(\widehat{\beta}_{A}^{i}-\widehat{\beta}_{B}^{i}\right)}{\bar{X}_{B}\left(\widehat{\beta}_{A}^{i}-\widehat{\beta}_{B}\right)}(4)
$$

Next, to examine changes in other distributional statistics besides the mean, we use a semi-parametric approach first developed by DiNardo, Fortin and Lemieux (1996), which we refer to as DFL. In its core, the DFL method is a reweighting procedure, which estimates a 
counterfactual distribution by replacing the marginal distribution of $\mathrm{X}$ for group $\mathrm{A}$ with the marginal distribution of $X$ for group $\mathrm{B}$, using a particular reweighting factor $\Psi(X)$. In practice the DFL method is similar to the propensity score method in the program evaluation literature (see Fortin, Lemieux, and Firpo 2010).

DiNardo, Fortin and Lemieux (1996) show that the expression for the reweighting factor, which is the ratio of two multivariate marginal distribution functions (of the covariates $\mathrm{X}$ ), can be simplified using Bayes's rule and estimated in practice by simply pooling the data for groups $\mathrm{A}$ and $\mathrm{B}$ and running a logit or probit model for the probability of belonging to group B:

$$
\begin{gathered}
\Psi(X)=\frac{d F_{X_{B}}(X)}{d F_{X_{A}}(X)} \\
\widehat{\Psi}(X)=\frac{\widehat{\operatorname{Pr}}\left(D_{B}=1 \mid X\right) / \widehat{\operatorname{Pr}} D_{B}=1}{\operatorname{Pr}\left(D_{B}=0 \mid X\right) / \operatorname{Pr} D_{B}=0}
\end{gathered}
$$

Then computing the counterfactual statistic of interest is done by using observations from the group A sample reweighted using $\widehat{\Psi}(X)$. In both decomposition methods we use the DE 1 (1931-1935) cohort as our reference group and we estimate the counterfactual statistics for the Gen X (1966-1975) cohort, assuming that it had the characteristics of the reference group.

While the biggest advantage of the reweighting decomposition method is that it allows us to examine characteristics of the distribution aside from the mean, such as the median, one limitation is that this technique is not straightforwardly extended to the case of the detailed decomposition. One approach that has been followed in the applied literature, and that we adopt in this paper, consists of the following: If our full model has 3 covariates such that $\operatorname{Pr}\left(D_{B}=1 \mid X_{1}, X_{2}, X_{3}\right)$, then the difference in the counterfactual distribution that one gets by reweighting with $X_{1}, X_{2}$ only, comparing with reweighting with $X_{1}, X_{2}, X_{3}$ should yield the appropriate contribution of $X_{3}$ to the composition effect. We present results from both the Oaxaca-Blinder and DFL methodologies.

In the main analysis, the $X$ vector includes two major components that could contribute to the difference across cohorts: marital status $(M)$ and labor supply $(L)$. The vector for marital status $(M)$ includes dummies for married, widowed, and divorced; and the vector for labor supply $(L)$ includes covered quarters and a measure of average lifetime earnings. ${ }^{13}$ In addition,

\footnotetext{
${ }^{13}$ Average lifetime earnings are constructed by averaging the individual's ratio of nominal earnings to the AWI over his working life.
} 
the model also controls for changes in education, race, and gender over time; these factors are grouped in $D$ vector. $\varepsilon$ is a random error term with mean zero.

\section{Decomposition Results}

Tables 2 and 3 summarize results from the decomposition of the changes in median benefit/tax ratios, median net tax rates, and the share with net transfers, between the oldest and youngest cohorts in our analysis, using the DFL technique described above. Table 2 presents decomposition results on an individual level and separately by gender, while Table 3 describes the decomposition results on a household level by marital status. Both tables compare the actual statistics for the DE 1 cohort and the Gen X cohort and also present the counterfactual outcome for the Gen X cohort, if it had the characteristics of the DE 1 cohort. Overall, on the individual level, the results show that differences in the characteristics between the oldest and youngest cohort can explain 30.7 percent of the difference in the observed median benefit/tax ratio, 49.3 percent of the difference in the median net tax rate and 34.1 percent of the difference in the share of individuals with positive transfers from the system.

Differences in the distribution of characteristics have high explanatory power for women, but almost none for men. On the other hand, the cohort differences in the median benefit/tax ratio, net tax rate, and share with positive transfers among men are several magnitudes smaller than those experienced by women. Figures 13 and 14 further confirm this result by allowing us to examine the whole distribution of the DE1 cohort benefit/tax ratios for men and women respectively, and to compare them with the actual and counterfactual (after DFL weighting) distributions of the Generation $\mathrm{X}$ benefit/tax ratios.

As figures 13 and 14 show, in contrast to men, the distribution of the benefit/tax ratio among women has changed dramatically between the DE1 and Generation X cohorts, and a significant share of the change is explained by differences in the characteristics of the two cohorts. In contrast, for men, the actual and counterfactual distribution of the benefit/tax ratio for the Generation X cohort virtually lie on top of each other, suggesting that the cohort differences are not driven by the differences in the cohort characteristics in our model.

Table 2 also provides information on the detailed decomposition, or how much of the total cohort difference in the outcome measures can be attributed to differences in each of the main factors - demographics, marital status, and labor supply. The results in Table 2, show that 
differences in labor supply between the cohorts account for 22 percent of the difference in the share of individuals with positive transfers, 37.8 percent of the difference in the median net tax rate and 23.9 percent of the difference in the median benefit/tax ratio. The explanatory power of labor supply is even bigger among women. On the other hand, differences in marital status have a relatively small effect, ranging from 4.6 to 7.4 percent, while differences in demographics have a negative contribution.

The household level analysis in Table 3 shows that the differences in the distribution of observable factors between the two cohorts can explain about 24.7 percent of the total observed difference in the median benefit/tax ratio for the never married, 27.4 percent for the divorced, and 39.6 percent for the married. The model, however, has negative explanatory power for the widowed. Cohort differences in characteristics can also explain 34.1 percent of the difference in the median net tax rate among the never married, 42.7 percent among the divorced, and 53.6 percent among the married. The higher explanatory power of the model for the married can also be seen in figures 15 (married) and 16 (non married) which show the whole distribution of the benefit/tax ratio for the DE1 cohort, together with the actual and counterfactual Gen X outcomes.

Table 3 further presents detailed decomposition results, highlighting the importance of labor force activity in explaining cohort differences on the household level too. Moreover, as Table 3 shows, differences in wife's labor force activity explain between 41.2 and 56.4 percent of the differences among married households, while husband's labor force activity has no explanatory power, even a negative contribution.

Finally, Tables 4 and 5 apply the Oaxaca-Blinder approach and show the detailed decompositions of the differences in the likelihood of receiving a positive transfer from Social Security, between individuals and married households in the DE 1 and Gen X cohorts. Overall, the results are similar in spirit to those in Tables 2 and 3 and show that differences in demographics, marital status, and labor force activity can explain a considerable portion of the cohort differences among women, but have no explanatory power among men. Among women only, changes in labor force activity explain 58.5 percent of the cohort difference in the likelihood of receiving transfers. Differences in marital status have a statistically significant but economically small effect of 2.9 percent of the total difference. The importance of the wife's labor activity in explaining cohort differences in the share with positive transfers among the 
married is again highlighted in Table 5. In contrast, the husband's labor force activity has a small in magnitude and statistically insignificant effect.

\section{Sensitivity Analysis}

\section{Alternative Discount Rates}

We perform sensitivity analysis with alternative discount rates that previous literature has used. Table 6 presents results of the median individual and household benefit/tax ratios using a discount rate of 2 percent (as in Brown, Coronado, and Fullerton, 2009), or using the historical 10-year T-bill rate, in combination with a 3.0 percent real rate for the future (similar to Coe et al. 2014). As expected, a lower discount rate reduces the weight on earlier payments of payroll taxes relative to the later receipt of benefits, resulting in a higher benefit/tax ratio for all cohorts. Using the alternative discount rates, we still find trends similar to our baseline scenario in terms of the evolution of benefit/tax ratios, net tax rates, and the propensity to receive positive transfers, by marital status and gender. ${ }^{14}$

\section{External Validity Test: Actual Earners in the HRS}

Table 7 summarizes the characteristics of the actual earners in the HRS. Marriage rates have declined across cohorts, and the labor force participation of women has increased (based on Social Security quarters of coverage). ${ }^{15}$ The share of individuals who are divorced or never married when they first claim has risen over time. Quarters of work have increased dramatically for women. These changes have increased the share of women eligible for Social Security retired-worker benefits based on their own earnings: only 50 percent of women were eligible for benefits as a retired worker for the DE1 cohort compared to 73 percent for the EBB. ${ }^{16}$ At the same time, the share of women eligible for only auxiliary benefits declined.

\footnotetext{
${ }^{14}$ Detailed results with the alternative discount rates are available from the authors upon request.

${ }^{15}$ Social Security pays retired-worker benefits to individuals who have accumulated 40 or more quarters of earnings in covered employment over their lives. Therefore, the average quarters of work is a crucial factor in benefit eligibility. An individual can earn up to 4 quarters of coverage per year. The amount of earnings for a quarter of coverage in 2012 was \$1,130. Since most jobs are covered by Social Security, Quarters of coverage is a good proxy for measuring the labor market attachment.

${ }^{16}$ See also Table 5.A14 in the Annual Statistical Supplement to the Social Security Bulletin (U.S. Social Security Administration 2011) for a similar comparison of the distribution of women's benefit entitlement over time.
} 
Using the HRS data and the methods described in section 3, we estimate the ratio of lifetime benefits to lifetime contributions from the DE1 cohort to the EBB at both the individual and household level.

Being consistent with the findings using MINT, the HRS results show a decline in the median ratio of lifetime benefits to lifetime contributions for all groups over time. The median benefit/tax ratio declined from 1.39 for the individuals of the DE1 cohort to 0.87 for EBB individuals (Table 8), and the decline is more dramatic for women than men (Table 9). The decline is also steeper for women who enter retirement married, or widowed, as compared to women who never married.

On a household basis, benefit/tax ratios are projected to decline from 1.35 to 0.82 between the DE1 and the EBB (Table 10). The decline is steepest for the married. While the gaps in transfers across different marital status groups appear to be shrinking over time, the HRS results show that those who have ever married still have a higher benefit/tax ratio compared to those who have never married.

Using the HRS sample, we also conducted the sensitivity tests using a real interest rate of 2.0 percent and a discount rate that reflects the historic return on long-term Treasury bonds. We find that the pattern of the evolution of benefit/tax ratios is consistent using alternative discount rates. $^{17}$

Comparing overlapped cohorts shows that MINT and HRS estimates of benefit/tax ratios are largely consistent, although MINT estimates are higher, and the estimated decline for the first four cohorts is smaller. For instance, while the HRS data show that benefit/tax ratios for all households declined by 39 percent between the DE1 and EBB cohorts (Table 10), MINT shows a decline of 21.3 percent (Figure 7).

The demographics of the MINT sample (Table 1) compared to those of the HRS (Table 7) reveal possible sources of the difference. Compared to the HRS (Table 6), the MINT sample is relatively more educated, more likely to be married, and less likely to be divorced or never married. In terms of labor force participation, the women of the HRS sample work more than those of MINT, particularly married women. Consequently, the proportion of women that is eligible for own retired worker benefits is higher for the HRS sample than for the MINT sample. In addition, across groups, beneficiaries in the HRS have higher AIMEs than those in MINT,

\footnotetext{
${ }^{17}$ The results are available from the authors upon request.
} 
which likely contributes to lower replacement rates on average, but higher taxes contributed to the system. Further, as the MINT sample is relatively more educated, the life expectancy is likely to be higher for the MINT sample, and this may lead to high lifetime benefits received. It is also worth noting that the mortality assumptions embedded in the HRS calculations are adjusted by age, race and education, while the mortality projection in MINT also adjusts for health. This study's scope does not include investigating which of MINT's embedded assumptions lead to these differences, but the differences between MINT and the HRS should be taken into account in assessing the difference in magnitudes of the results using different datasets.

In sum, despite the fact that the MINT estimates are higher and the estimated decline for the first four cohorts is smaller, the results of the HRS are largely consistent with the findings using the MINT: those who have ever married still have a higher benefit/tax ratio than those who have never married.

\section{Conclusion and Future Work}

This paper examines the extent to which Social Security continues to favor couples and will do so in the future. It estimates changes in three measures of redistributions of Social Security by marital status at both the household and individual level over time and for future retirees. The results show that while benefit/tax ratios and the share of individuals receiving positive transfers from Social Security are declining for both individuals and households, on a household basis all examined cohorts are projected to have median benefit/tax ratios above one and more than half will be receiving positive transfers from the Social Security system. Further, the decomposition analysis shows that the increased labor force participation and earnings of women have contributed significantly to the decline in redistribution from men to women, and from never married to married, while the effect of declining marriage rates has only a modest effect.

As Congress seeks ways to reform Social Security to address insolvency, changes to family benefit provisions may well be on the table. The findings of this paper may help in evaluating various reform proposals to change the benefits structure. 


\section{References}

Biggs, Andrew G., Mark Sarney, and Christopher R. Tamborini. 2009. “A Progressivity Index for Social Security.” Issue Paper \#2009-01. Washington, DC: Social Security Administration, Office of Retirement and Disability Policy.

Brown, Jeffrey R., Julia L. Coronado, Don Fullerton. 2009. “Is Social Security Part of the Social Safety Net?” in Tax Policy and the Economy, Volume 23. Chicago, IL: University of Chicago Press.

Brown, Jeffrey R., Jeffrey B. Liebman, and Joshua Pollet. 2002. "Estimating Life Tables that Reflect Socioeconomic Differences in Mortality.” In The Distributional Effects of Social Security Reform, edited by M. Feldstein and J. Liebman, 447-457. Chicago IL: University of Chicago Press.

Butrica, Barbara A. and Karen E. Smith. 2012. "The Impact of Changes in Couples' Earnings on Married Women Social Security Benefits.” Social Security Bulletin 72(1).

Caldwell, Steven, Melissa Favreault, Alla Gantman, Jagdeesh Gokhale, Thomas Johnson, and Laurence J. Kotlikoff. 1999. "Social Security’s Treatment of Postwar Americans.” Tax Policy and the Economy 13: 109-48.

Coe, Norma B., Zhenya Karamcheva, Richard Kopcke, and Alicia H. Munnell. 2014 (forthcoming). “ How Does the Personal Income Tax Affect the Progressivity of OASI Benefits?” National Tax Journal.

Cohen, Lee, C. Eugene Steuerle and Adam Carasso. 2001. "Social Security Redistribution by Education, Race and Income: How Much and Why?” Paper presented at the Third Annual Joint Conference of the Retirement Research Consortium. Washington, DC. Available at: http://www.mrrc.isr.umich.edu/publications/conference/pdf/cp01_carasso.pdf.

Coronado, Julia Lynn, Don Fullerton, and Thomas Glass. 2011. “The Progressivity of Social Security.” The B.E. Journal of Economic Analysis \& Policy 11(1).

DiNardo, John, Nicole M. Fortin, and Thomas Lemieux. 1996. "Labor Market Institutions and the Distribution of Wages, 1973-1992: A Semiparametric Approach.” Econometrica 64: 1001-1044.

Favreault, Melissa M., and C. Eugene Steuerle. 2007. "Social Security Spouse and Survivor Benefits for the Modern Family.” Discussion Paper 07-01. Washington, DC: The Urban Institute.

Fortin, Nicole, Thomas Lemieux, and Sergio Firpo. 2010. "Decomposition Methods in Economics.” in Handbook of Labor Economics, edited by D. Card and O. Ashenfelter, 4th Edition, 1-102. Amsterdam, Netherlands: Elsevier. 
Firpo, Sergio, Nicole M. Fortin, and Thomas Lemieux. 2009. “Unconditional Quantile Regressions.” Econometrica 77(3): 953-973.

Gustman, Alan L. and Thomas L. Steinmeier. 2001. "How Effective is Redistribution under the Social Security Benefit Formula?” The Journal of Public Economics 82(1): 1-28.

Harrington Meyer, Madonna, Douglas A. Wolf, and Christine L. Himes. 2004. "Linking Benefits to Marital Status: Race and Diminishing Access to Social Security Spouse and Widow Benefits in the U.S.” Working Paper 2004-05. Chestnut Hill, MA: Center for Retirement Research at Boston College.

Hamermesh, Daniel S. and Albert Rees. 1993. The Economics of Work and Pay. New York, NY: Harper Collins College Publishers.

Kiefer, Donald W. 1984. "Distributional Tax Redistribution Indexes.” National Tax Journal 37(4): 497-513.

Lerman, Robert I. and Shlomo Yitzhaki. 1995. "Changing Ranks and Inequality Impacts of Taxes and Transfers.” National Tax Journal 48(1): 45-59.

Liebman, Jeffrey B. 2002. "Redistribution in the Current U.S. Social Security System.” In The Distributional Effects of Social Security and Social Security Reform, edited by Martin Feldstein and Jeffrey B. Liebman, 11-48. Chicago, IL: University of Chicago Press.

Machado, J. A. and J. Mata 2005. "Counterfactual Decomposition of Changes in Wage Distribution Using Quantile Regression.” Journal of Applied Econometrics 20: 445-465.

Piketty, Thomas and Emmanuel Saez. 2007. "How Progressive Is the U.S. Federal Tax System? A Historical and International Perspective.” Journal of Economic Perspectives 21(1): 324.

Schwartz, Christine. 2010. "Earnings Inequality and the Changing Association between Spouses' Earnings.” American Journal of Sociology 115(5): 1524-1557.

Social Security Administration. 2012. 2012 Annual Report of the Board of Trustees of the Federal Old-Age and Survivors Insurance and Disability Insurance Trust Funds. Washington, DC: Government Printing Office.

Wu, April Yanyuan, Nadia Karamcheva, Alicia H. Munnell, and Patrick Purcell. 2013. "How Do the Changing Labor Supply Behavior and Marriage Patterns of Women Affect Social Security Replacement Rates?” Social Security Bulletin 73(4). 
Figure 1. Social Security Benefit Status of Women at Social Security Take-Up Age, by Cohort

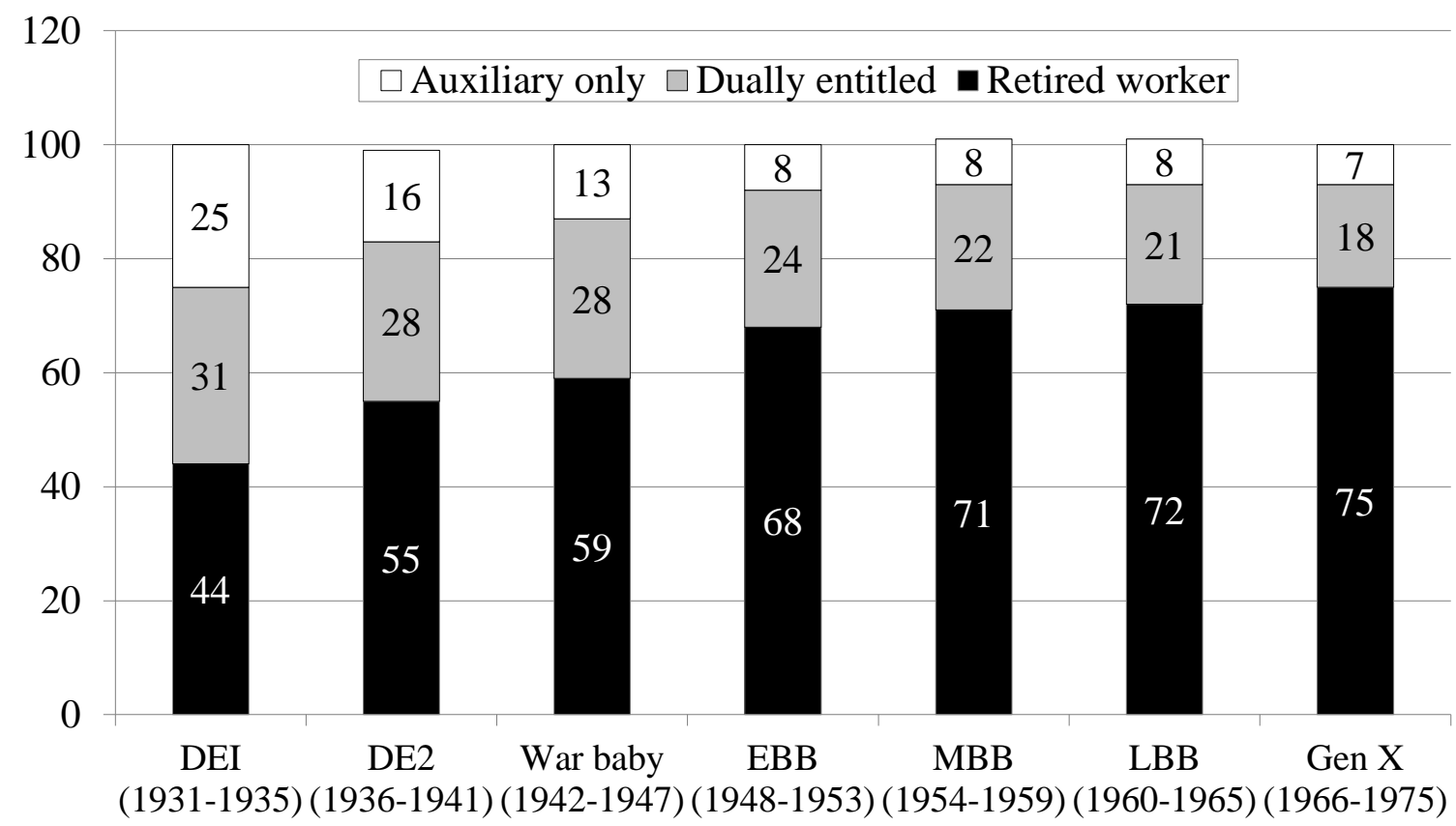

Note: Percentages for women in three youngest cohorts are projected.

Source: Authors' calculations based on data from MINT 5 and MINT 6.

Figure 2. Share of Women at Social Security Take-Up Age Who Would Receive Higher Benefits as a Survivor, by Cohort

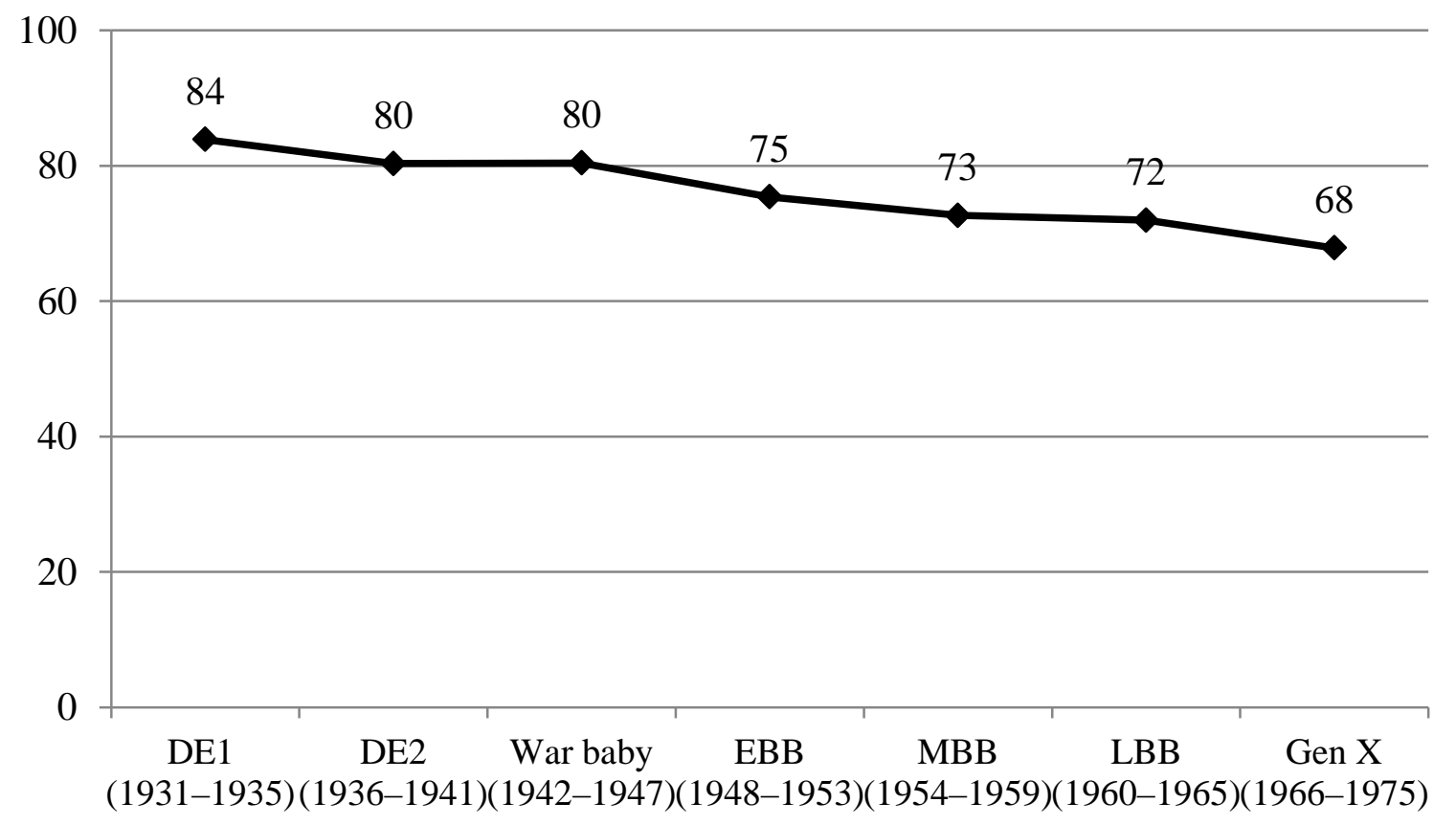

Note: Percentages for women in three youngest cohorts are projected.

Source: Authors' calculations based on data from MINT 5 and MINT 6. 
Figure 3. Estimated Median Individual Benefit/Tax Ratios, by Marital Status, and Birth Cohort

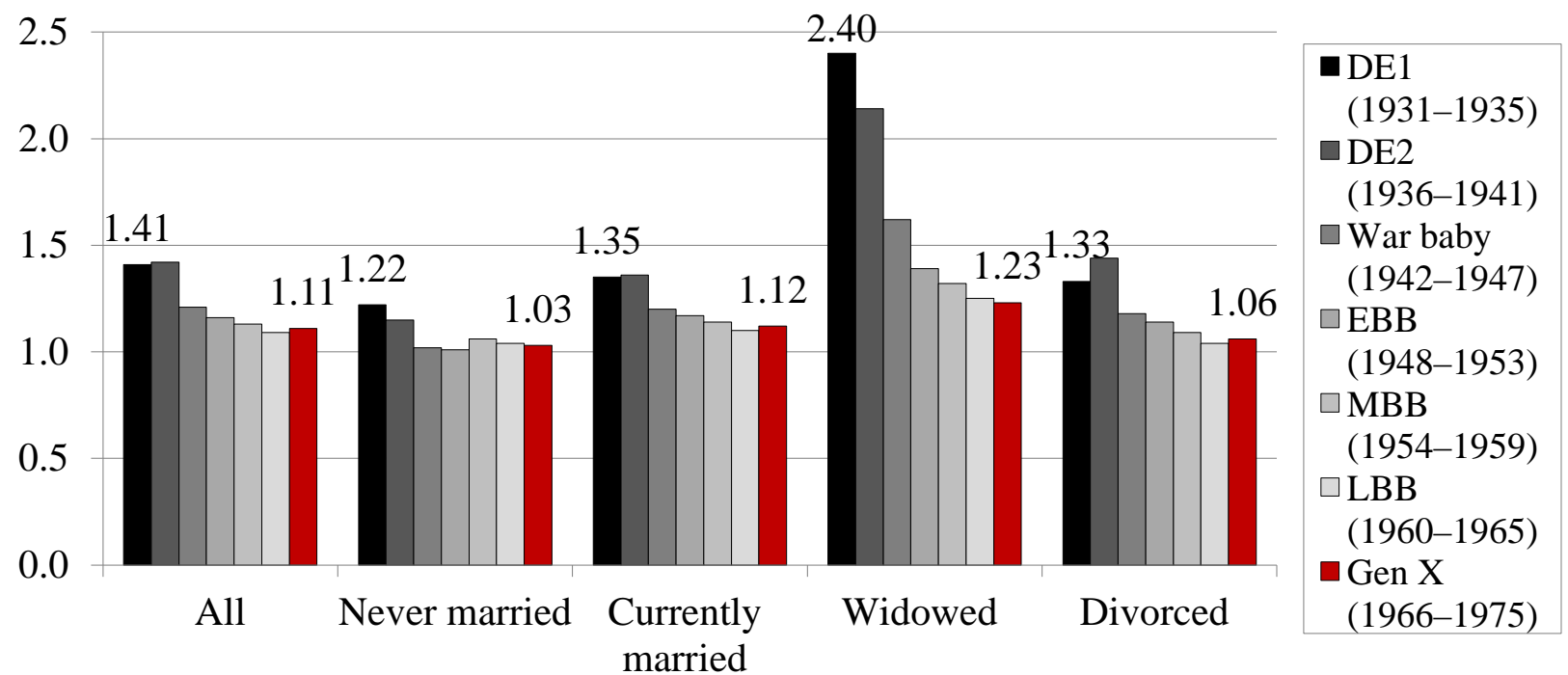

Note: "Benefit/tax ratio" is defined as the PV of Social Security benefits divided by PV of payroll taxes paid. Assumed real interest rate of 2.9 percent.

Source: Authors' calculations based on MINT 5 and MINT 6.

Figure 4. Estimated Median Individual Benefit/Tax Ratios by Marital Status, and Birth Cohort, Men Only

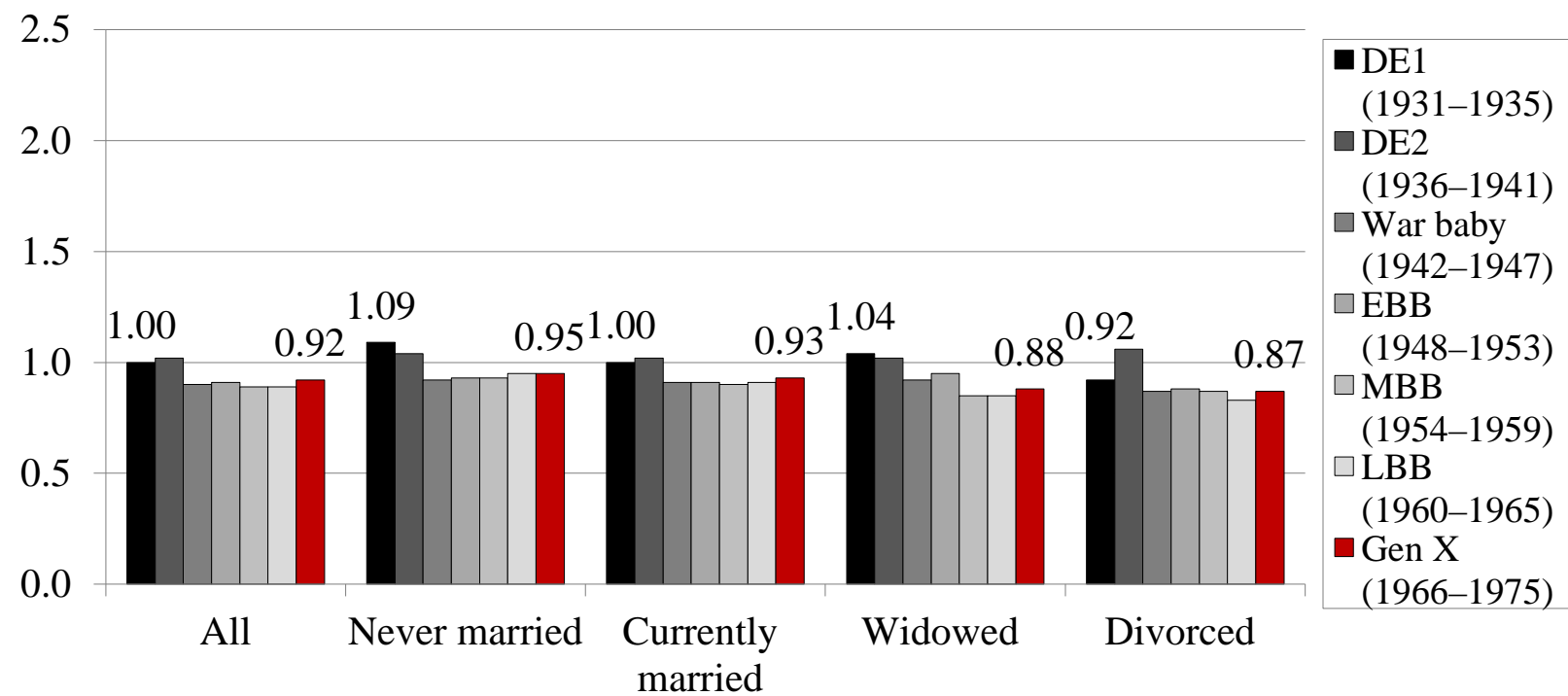

Note: "Benefit/tax ratio" is defined as the PV of Social Security benefits divided by PV of payroll taxes paid. Assumed real interest rate of 2.9 percent.

Source: Authors' calculations based on MINT 5 and MINT 6. 
Figure 5. Estimated Median Individual Benefit/Tax Ratios by Marital Status, and Birth Cohort: Women Only

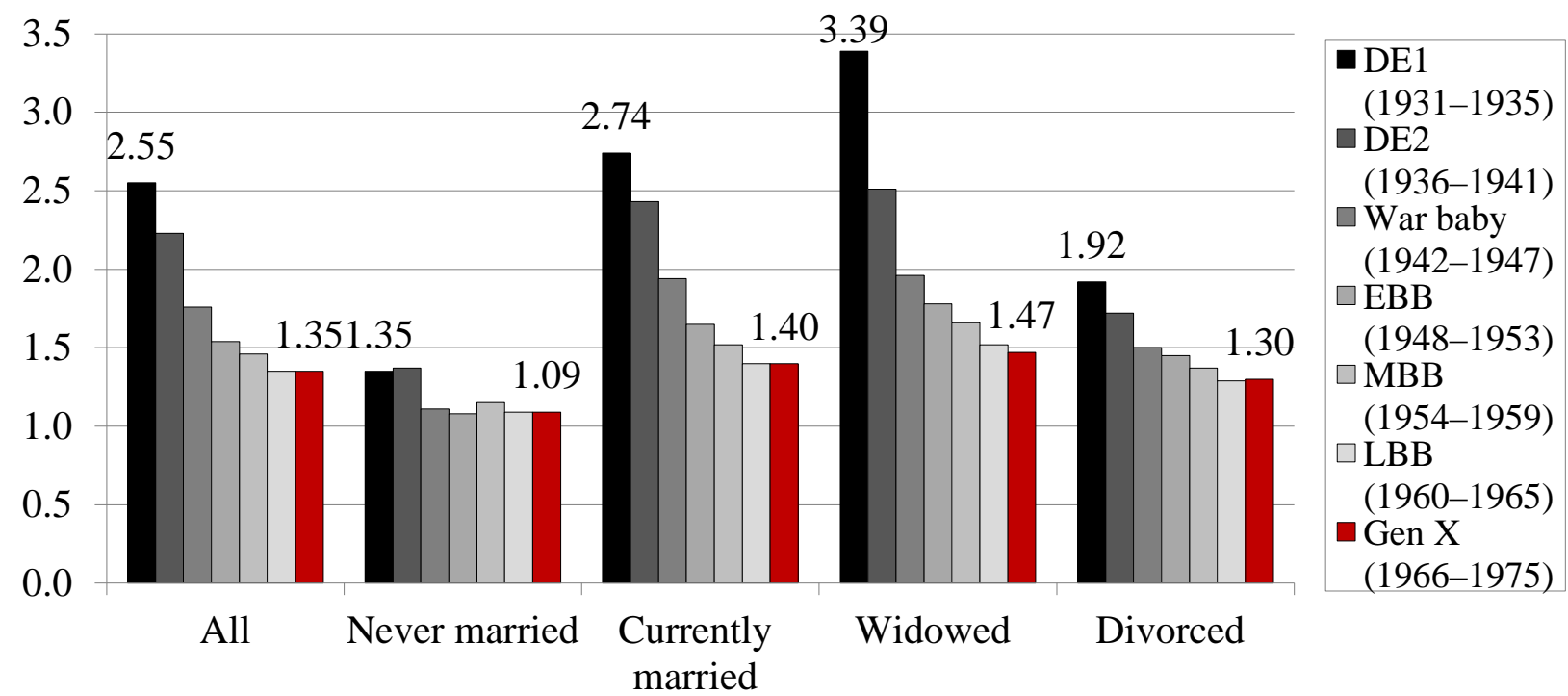

Note: "Benefit/tax ratio" is defined as the PV of Social Security benefits divided by PV of payroll taxes paid. Assumed real interest rate of 2.9 percent.

Source: Authors' calculations based on MINT 5 and MINT 6.

Figure 6. Estimated Individual Median Net Tax Rates by Marital Status and Birth Cohort

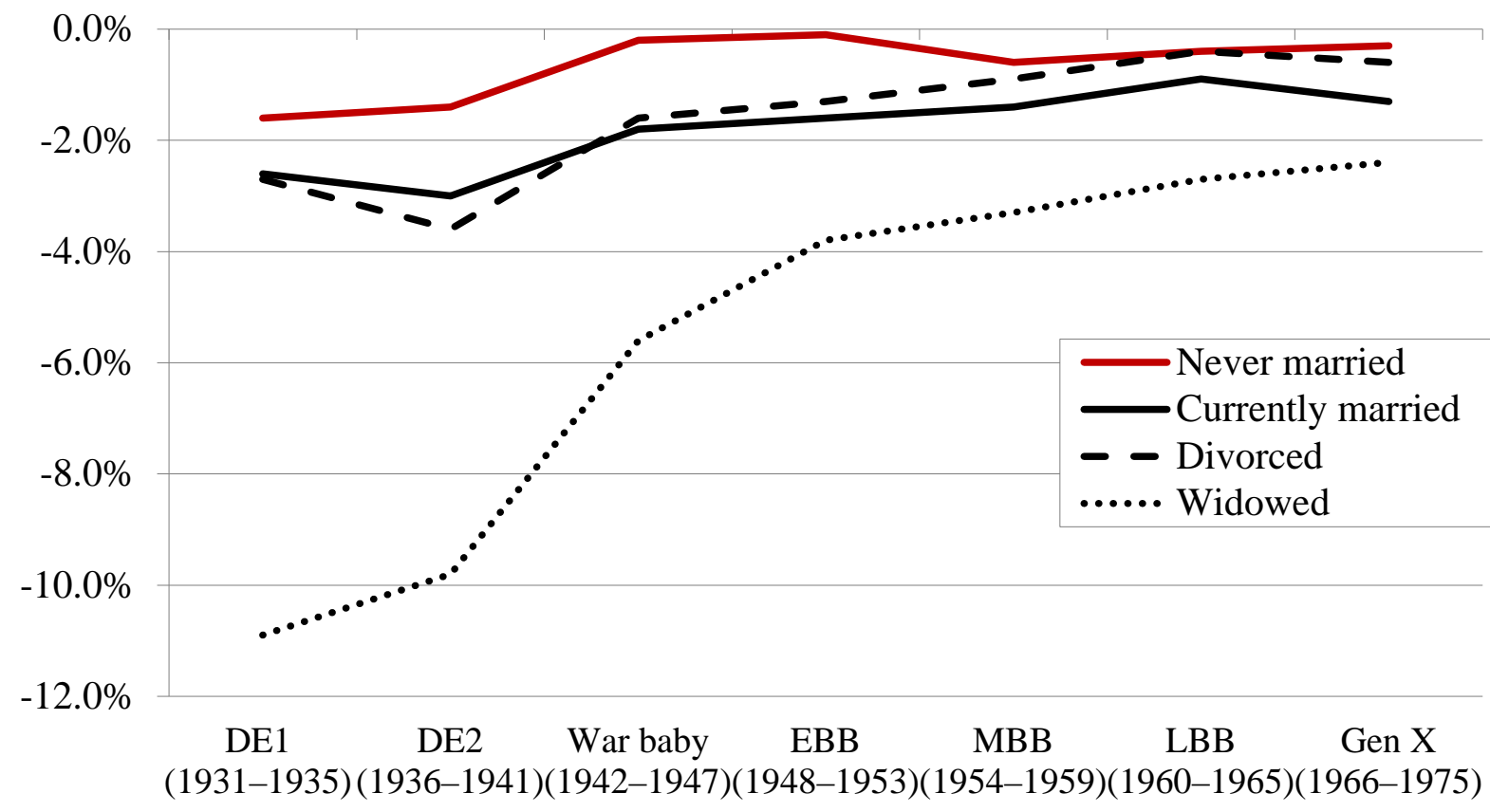

Note: "Net tax rate” is defined as (PV of SS contributions - PV of SS benefits)/PV of uncapped lifetime earnings. Assumed real interest rate of 2.9 percent.

Source: Authors' calculations based on MINT 5 and MINT 6. 
Figure 7. Estimated Median Household Benefit/Tax Ratios, by Marital Status and Birth Cohort

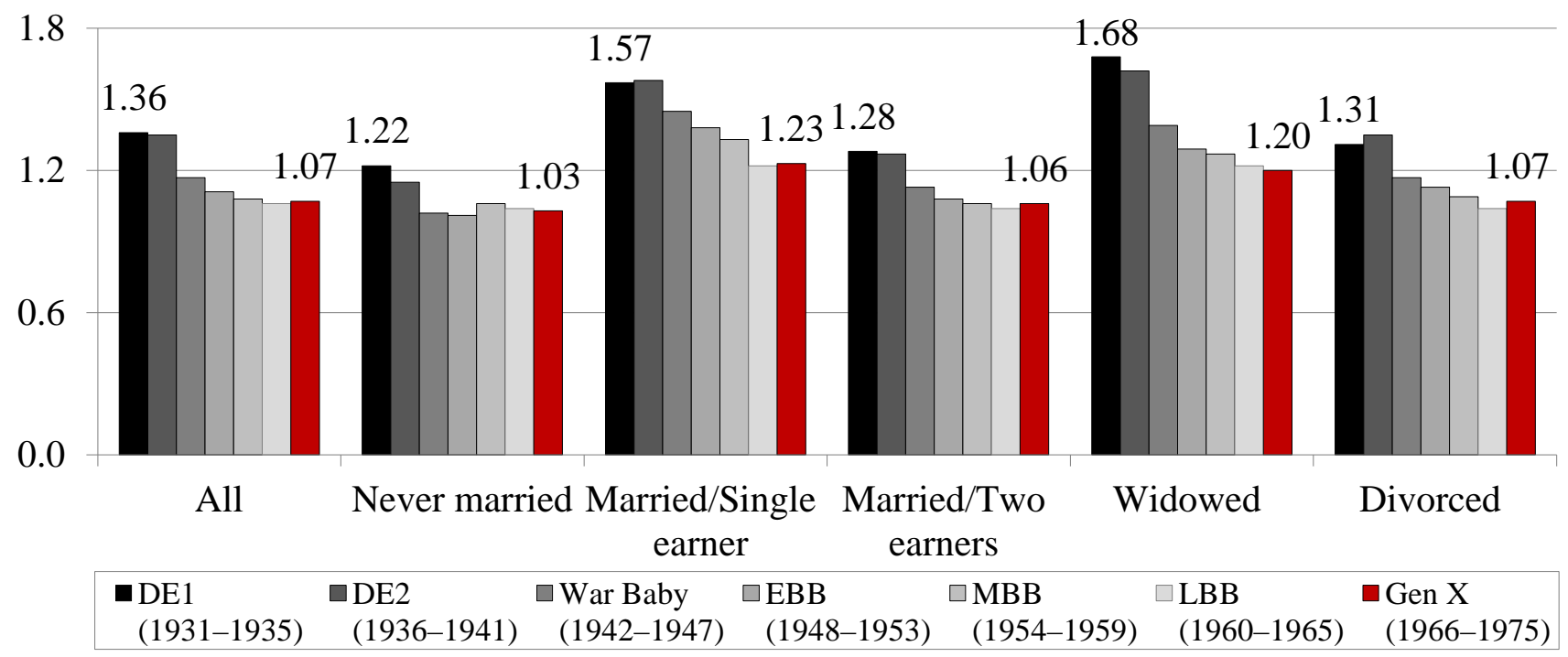

Note: "Benefit/tax ratio" is defined as the PV of Social Security benefits divided by PV of payroll taxes paid. Assumed real interest rate of 2.9 percent.

Source: Authors' calculations based on MINT 5 and MINT 6.

Figure 8. Estimated Median Household Net Tax Rate from Social Security, by Marital Status and Birth Cohort

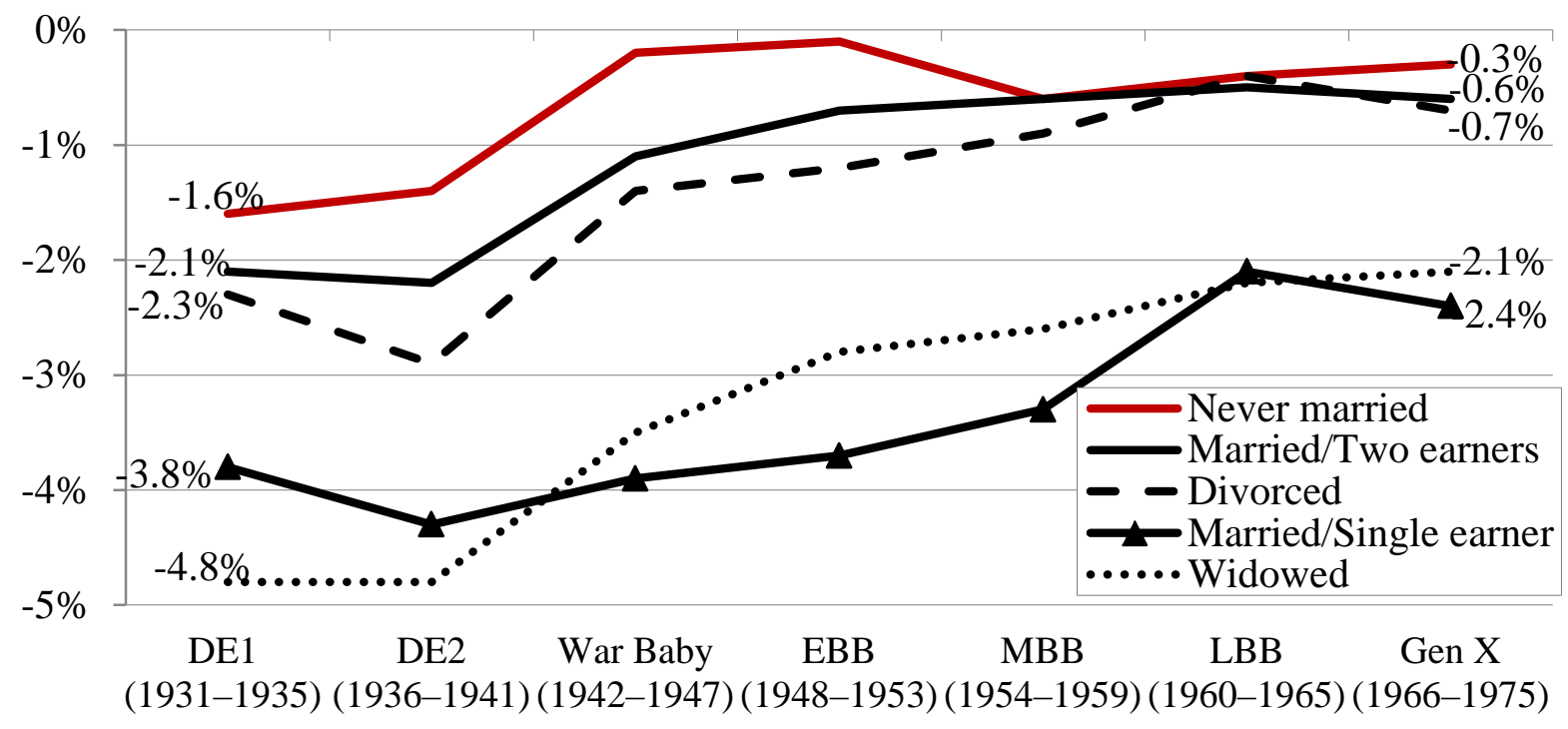

Note: "Net tax rate” is defined as (PV of SS contributions - PV of SS benefits)/PV of uncapped lifetime earnings. Assumed real interest rate of 2.9 percent.

Source: Authors' calculations based on MINT 5 and MINT 6. 
Figure 9. Estimated Share of Households Receiving Positive Transfers from Social Security, by Marital Status and Birth Cohort

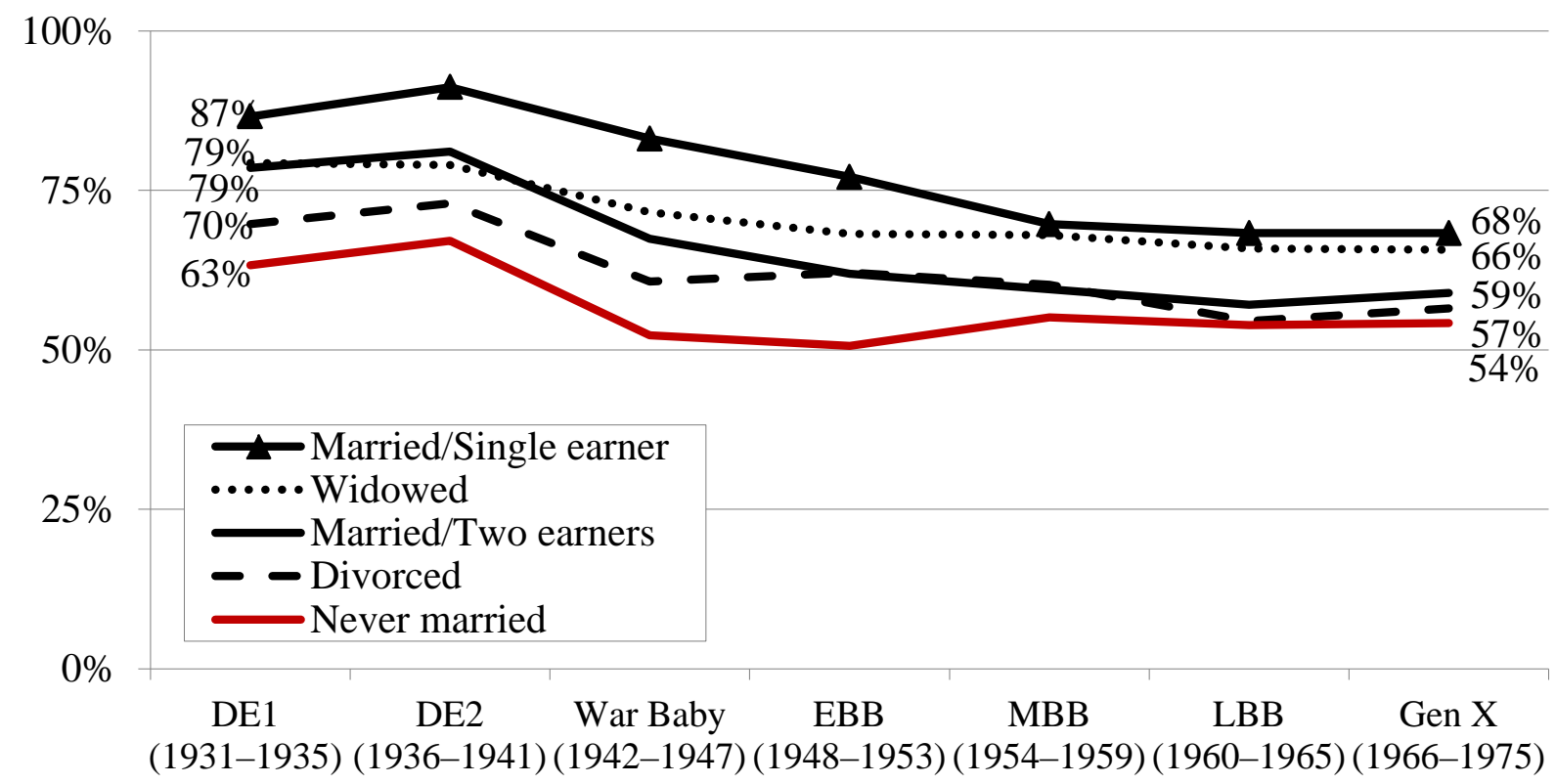

Note: "Receiving positive transfers" is equivalent to having a negative net tax rate, defined as (PV of SS contributions - PV of SS benefits)/PV of uncapped lifetime earnings. Assumed real interest rate of 2.9 percent. Source: Authors' calculations based on MINT 5 and MINT 6.

Figure 10. Estimated Median Household Benefit/Tax Ratios for Married-Couple Households, by Number of Earners, Husband's Earnings Tercile, and Birth Cohort

\begin{tabular}{|lllllll|}
\hline$\square$ DE1 & $\square$ DE2 & $\square$ War Baby & $\square$ EBB & $\square$ MBB & $\square$ LBB & $\square$ Gen X \\
$(1931-1935)$ & $(1936-1941)$ & $(1942-1947)$ & $(1948-1953)$ & (1954-1959) & (1960-1965) & $(1966-1975)$ \\
\hline
\end{tabular}

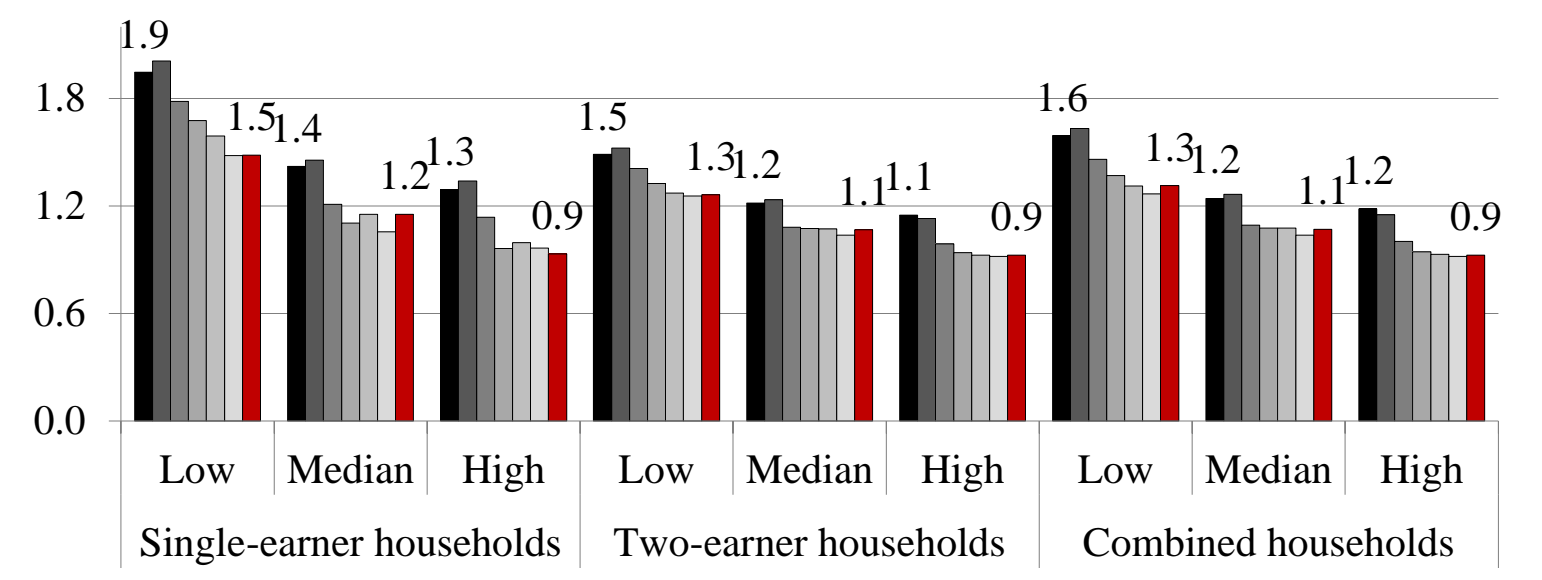

Note: "Benefit/tax ratio" is defined as the PV of Social Security benefits divided by PV of payroll taxes paid. Assumed real interest rate of 2.9 percent. Husband's earnings are approximated by his AIME, calculated using total earnings, including those above the cap.

Source: Authors' calculations based on MINT 5 and MINT 6. 
Figure 11. Estimated Median Household Net Tax Rate for Married-Couple Households, by Number of Earners, Husband's Earnings Tercile, and Birth Cohort

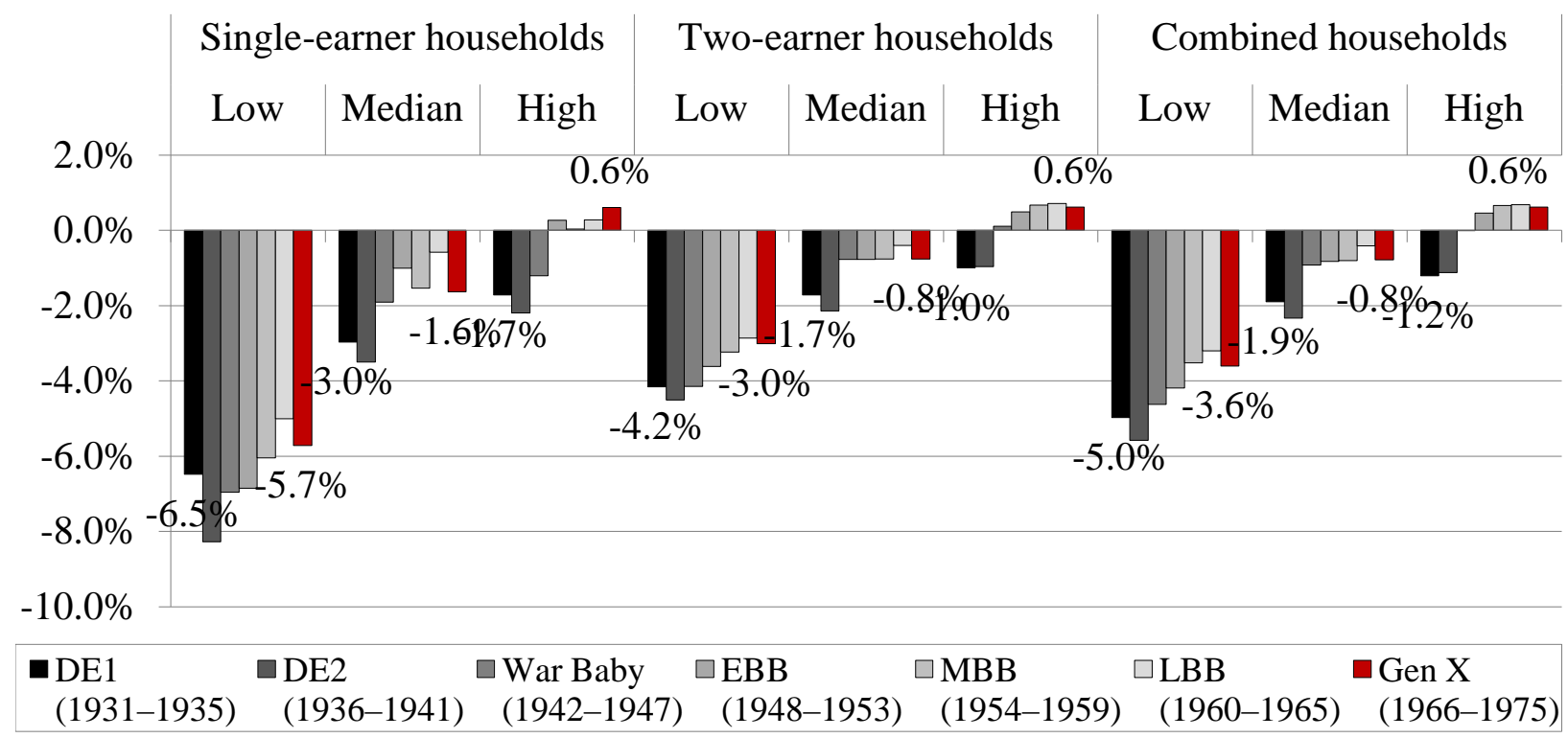

Note: "Net tax rate" is defined as (PV of SS contributions - PV of SS benefits)/PV of uncapped lifetime earnings. Assumed real interest rate of 2.9 percent. Husband's earnings are approximated by his AIME, calculated using total earnings, including those above the cap.

Source: Authors' calculations based on MINT 5 and MINT 6.

Figure 12. Estimated Share of Married-Couple Households Receiving Positive Transfers from Social Security, by Number of Earners, Husband's Earnings Tercile, and Birth Cohort

\begin{tabular}{|lllllll|}
\hline DE1 & $\square$ DE2 & $\square$ War Baby & $\square$ EBB & $\square$ MBB & $\square$ LBB & $\square$ Gen X \\
$(1931-1935)$ & $(1936-1941)$ & $(1942-1947)$ & $(1948-1953)$ & $(1954-1959)$ & $(1960-1965)$ & $(1966-1975)$ \\
\hline
\end{tabular}

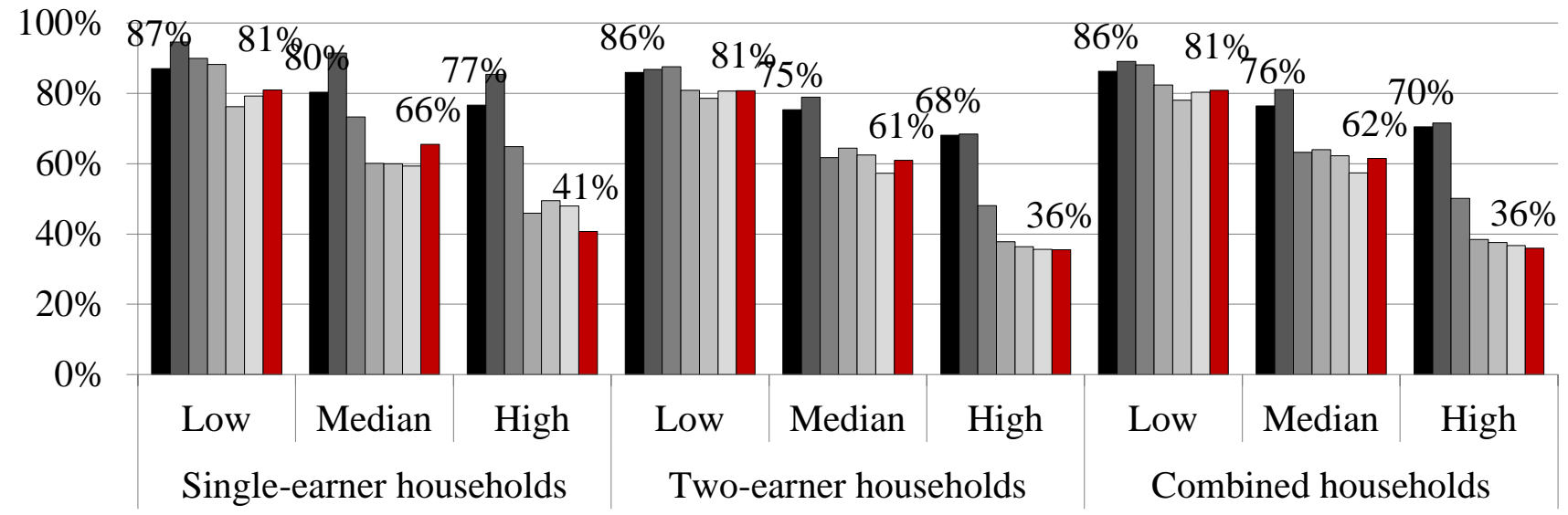

Note: "Receiving positive transfers" is equivalent to having a negative net tax rate, defined as (PV of SS contributions - PV of SS benefits)/PV of uncapped lifetime earnings. Assumed real interest rate of 2.9 percent . Husband's earnings are approximated by his AIME, calculated using total earnings, including those above the cap. Source: Authors' calculations based on MINT 5 and MINT 6. 
Figure 13. Actual and Counterfactual Distribution of Lifetime Ratio of Benefits to Contributions among Men: DFL Approach

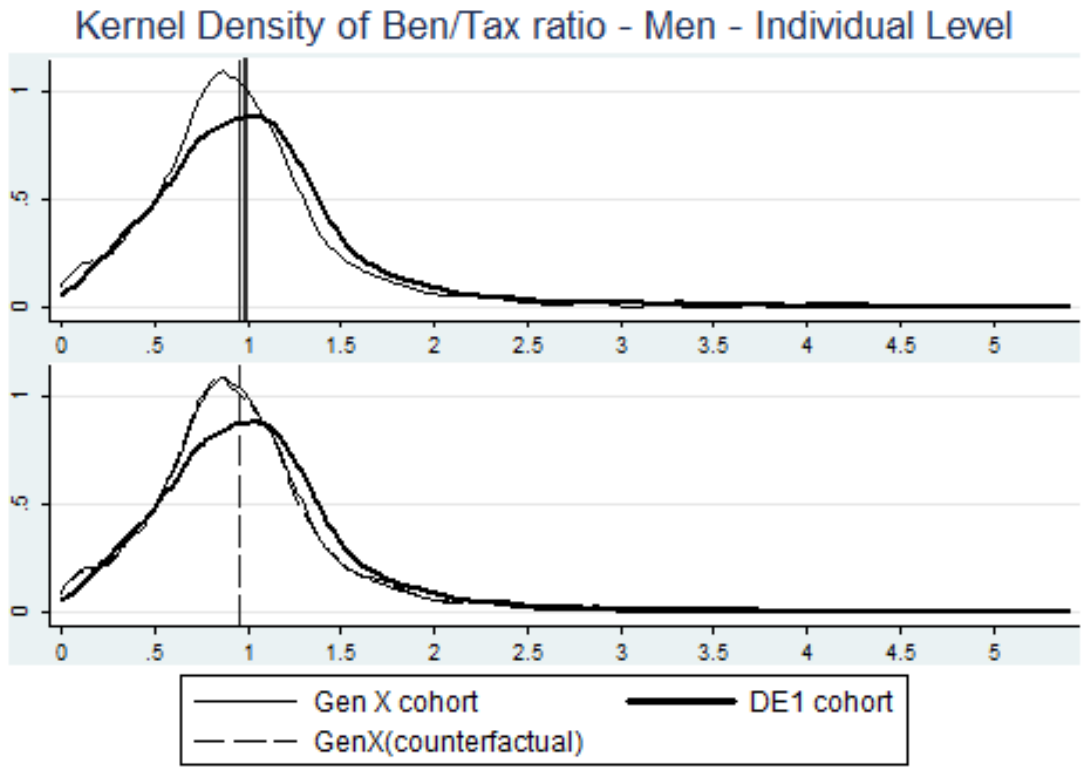

Note: Vertical lines denote median values. The figure excludes upper 1 percentile of the distribution. Source: Author's calculations based on data from MINT 5 and MINT 6.

Figure 14. Actual and Counterfactual Distribution of Lifetime Ratio of Benefits to Contributions among Women: DFL Approach

Kernel Density of Ben/Tax ratio - Only Women - Individual Level

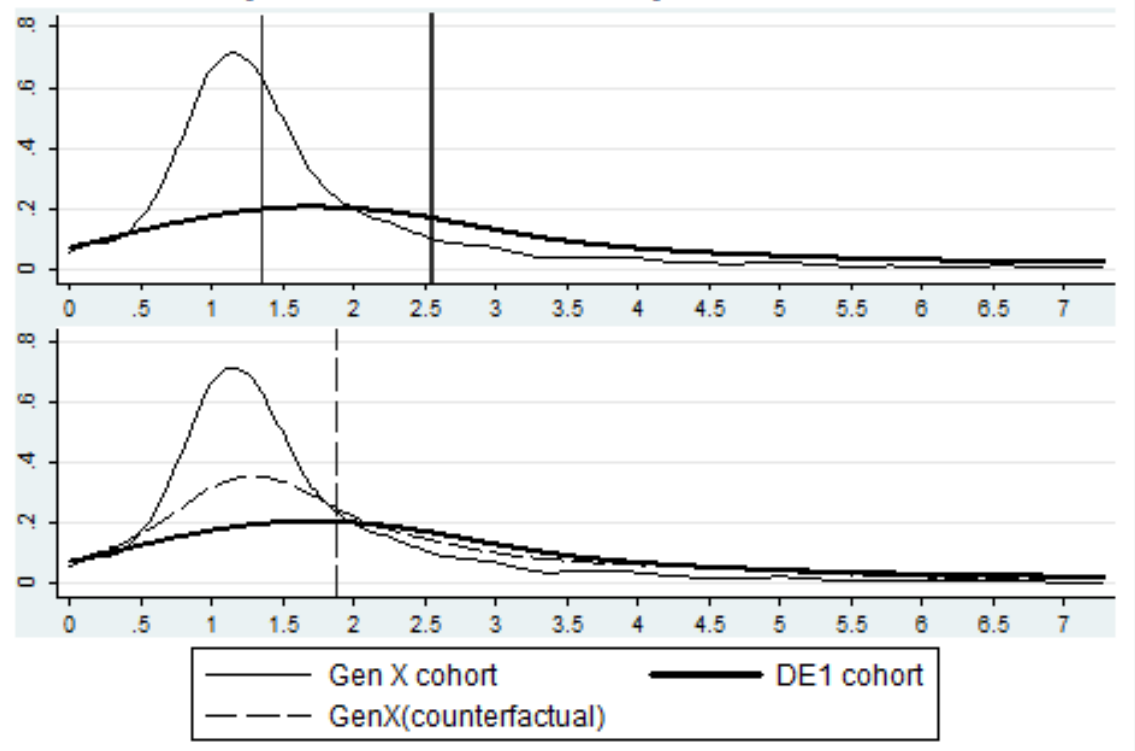

Note: Vertical lines denote median values. The figure excludes the upper 10 percentile of the distribution. Source: Authors' calculations based on data from MINT 5 and MINT 6. 
Figure 15. Actual and Counterfactual Distribution of Lifetime Ratio of Benefits to Contributions among Married Households: DFL Approach

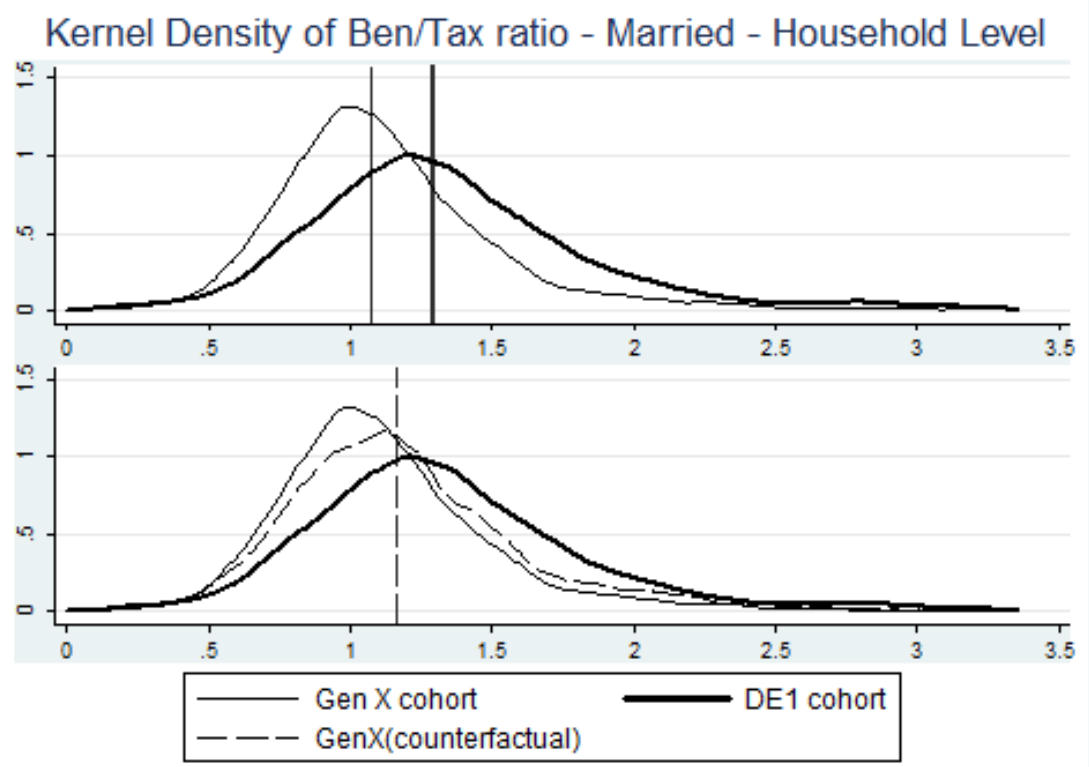

Note: Vertical lines denote median values. The figure excludes upper 1 percentile of the distribution. Source: Authors' calculations based on data from MINT 5 and MINT 6.

Figure 16. Actual and Counterfactual Distribution of Lifetime Ratio of Benefits to Contributions among Not-married Households: DFL Approach

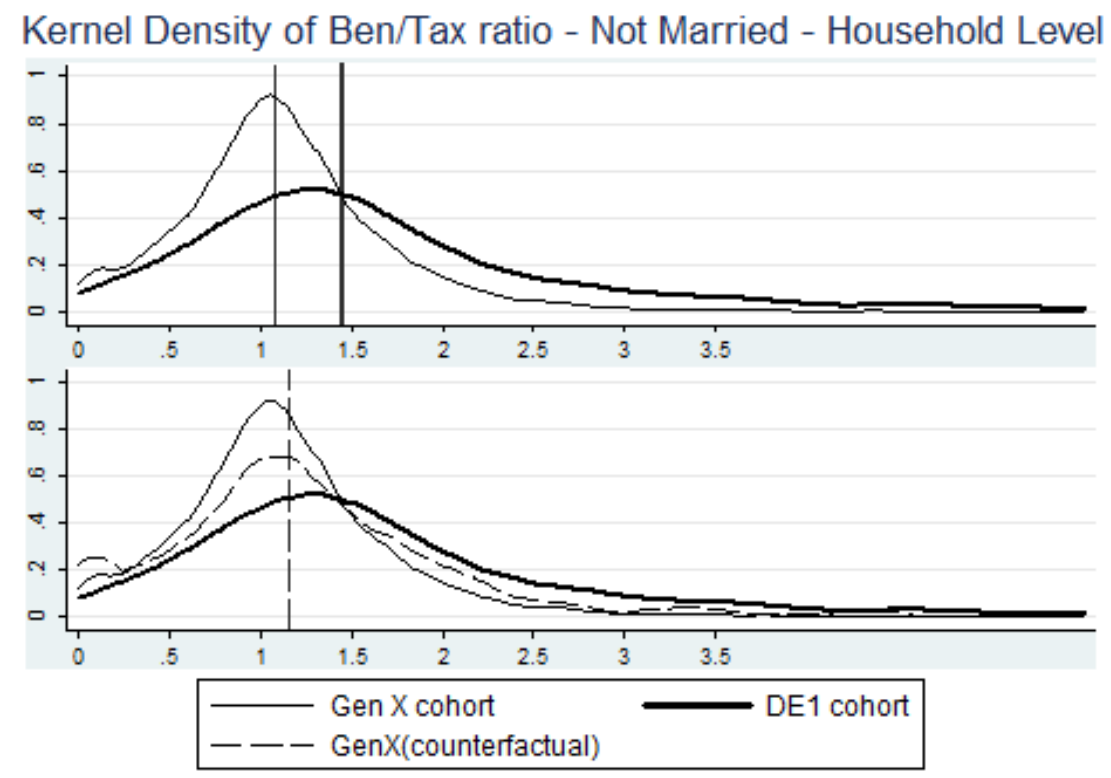

Note: Vertical lines denote median values. The figure excludes upper 1 percentile of the distribution. Source: Authors' calculations based on data from MINT 5 and MINT 6. 
Table 1. Characteristics of Individuals when First Claiming Social Security Benefits, by Birth Cohort

\begin{tabular}{|c|c|c|c|c|c|c|c|}
\hline Characteristic & $\begin{array}{c}\text { DE1 } \\
(1931- \\
1935) \\
\end{array}$ & $\begin{array}{c}\text { DE2 } \\
(1936- \\
1941)\end{array}$ & $\begin{array}{c}\text { War baby } \\
(1942- \\
1947) \\
\end{array}$ & $\begin{array}{c}\text { EBB } \\
(1948- \\
1953) \\
\end{array}$ & $\begin{array}{c}\text { MBB } \\
(1954- \\
1959) \\
\end{array}$ & $\begin{array}{c}\text { LBB } \\
(1960- \\
1965) \\
\end{array}$ & $\begin{array}{c}\text { Gen X } \\
(1966- \\
1975) \\
\end{array}$ \\
\hline & \multicolumn{7}{|c|}{ Percentage distributions } \\
\hline \multicolumn{8}{|l|}{ Sex } \\
\hline Men & 46.8 & 47.2 & 47.1 & 46.2 & 46.9 & 47.4 & 47.6 \\
\hline Women & 53.2 & 52.8 & 52.9 & 53.8 & 53.1 & 52.6 & 52.4 \\
\hline \multicolumn{8}{|l|}{ Marital status } \\
\hline Married & 73.8 & 72.1 & 68.1 & 63.4 & 61.1 & 60.5 & 58.5 \\
\hline Divorced & 10.6 & 12.9 & 17.6 & 19.4 & 20.1 & 20.3 & 21.0 \\
\hline Never married & 3.5 & 3.8 & 4.8 & 6.5 & 7.7 & 8.2 & 10.3 \\
\hline Widowed & 12.1 & 11.2 & 9.6 & 10.8 & 11.1 & 11.0 & 10.2 \\
\hline \multicolumn{8}{|l|}{ Education } \\
\hline $\begin{array}{l}\text { Less than high } \\
\text { school } \\
\text { High school }\end{array}$ & 20.6 & 13.9 & 9.0 & 6.4 & 7.3 & 7.2 & 8.1 \\
\hline $\begin{array}{l}\text { degree } \\
\text { At least some }\end{array}$ & 58.8 & 61.6 & 59.8 & 58.2 & 60.3 & 59.0 & 54.6 \\
\hline \multirow{2}{*}{$\begin{array}{l}\text { At least some } \\
\text { college }\end{array}$} & 20.6 & 24.5 & 31.2 & 35.4 & 32.4 & 33.8 & 37.3 \\
\hline & \multicolumn{7}{|c|}{ Cohort average values } \\
\hline \multicolumn{8}{|l|}{ Women } \\
\hline Married & 75 & 86 & 99 & 110 & 117 & 119 & 120 \\
\hline Divorced & 106 & 107 & 121 & 129 & 131 & 131 & 129 \\
\hline Never married & 124 & 132 & 132 & 142 & 134 & 140 & 137 \\
\hline Widowed & 84 & 92 & 106 & 113 & 116 & 119 & 117 \\
\hline \multicolumn{8}{|l|}{ Men } \\
\hline Married & 141 & 143 & 144 & 143 & 144 & 146 & 142 \\
\hline Divorced & 137 & 135 & 142 & 139 & 144 & 148 & 147 \\
\hline Never married & 127 & 132 & 131 & 136 & 133 & 135 & 140 \\
\hline Widowed & 139 & 141 & 134 & 137 & 141 & 141 & 137 \\
\hline & \multicolumn{7}{|c|}{ AIME (annual, household level, 2012 dollars) } \\
\hline \multicolumn{8}{|l|}{ Marital status } \\
\hline Married & 48,474 & 58,188 & 69,901 & 77,339 & 84,564 & 90,867 & 96,205 \\
\hline Divorced & 24,499 & 28,366 & 35,004 & 36,661 & 41,158 & 44,629 & 49,003 \\
\hline Never married & 25,829 & 31,681 & 37,679 & 40,096 & 40,939 & 43,625 & 51,373 \\
\hline Widowed & 21,491 & 25,465 & 29,014 & 32,608 & 36,855 & 39,889 & 40,475 \\
\hline
\end{tabular}


Table 1. Characteristics of Individuals when First Claiming Social-Security Benefits, by Birth Cohort (cont'd)

\begin{tabular}{l|c|c|c|c|c|c|c}
\hline & DE1 & DE2 & War baby & EBB & MBB & LBB & Gen X \\
& $(1931-$ & $(1936-$ & $(1942-$ & $(1948-$ & $(1954-$ & $(1960-$ & $(1966-$ \\
Characteristic & $1935)$ & $1941)$ & $1947)$ & $1953)$ & $1959)$ & $1965)$ & $1975)$ \\
\hline
\end{tabular}

\section{Cohort average values (cont.)}

Benefit amount (annual, household level, 2012 dollars)

\begin{tabular}{|c|c|c|c|c|c|c|c|}
\hline \multicolumn{8}{|l|}{ Marital status } \\
\hline Married & 22,126 & 25,536 & 28,888 & 31,400 & 33,225 & 32,046 & 33,647 \\
\hline Divorced & 12,397 & 13,012 & 15,620 & 16,360 & 17,543 & 17,063 & 18,148 \\
\hline $\begin{array}{l}\text { Never } \\
\text { married }\end{array}$ & 11,290 & 13,533 & 14,908 & 16,043 & 16,260 & 15,209 & 17,291 \\
\hline Widowed & 13,264 & 14,439 & 16,062 & 17,004 & 18,300 & 17,606 & 18,353 \\
\hline & \multicolumn{7}{|c|}{ Age when claiming (years) } \\
\hline All & 63.5 & 63.4 & 63.9 & 64.3 & 64.1 & 64.1 & 64.1 \\
\hline Men & 63.9 & 63.7 & 64.0 & 64.5 & 64.3 & 64.4 & 64.4 \\
\hline Women & 63.3 & 63.2 & 63.7 & 64.1 & 63.9 & 63.8 & 63.8 \\
\hline
\end{tabular}

Note: Percentages for women in three youngest cohorts are projected.

Source: Authors' calculations based on data from MINT 5 and MINT 6. 
Table 2. Decomposing Changes in Median lifetime ratio of benefits to contributions, median net tax rate and share with net transfers: Individual level: DFL approach

\begin{tabular}{|c|c|c|c|c|c|c|c|}
\hline & $\begin{array}{c}\text { DE1 } \\
(1931-1935)\end{array}$ & $\begin{array}{c}\text { Gen X } \\
(1966-1975)\end{array}$ & $\begin{array}{c}\text { Counterfactual } \\
\text { Gen X } \\
(1966-1975) \\
\end{array}$ & $\begin{array}{c}\text { Share of the Change } \\
\text { Attributed to Differences } \\
\text { in Characteristics \% }\end{array}$ & \multicolumn{3}{|c|}{ Share of the Change attributed to Differences in } \\
\hline Statistic & & & & & Demographics & Marital Status & Labor Supply \\
\hline \multicolumn{8}{|l|}{ All Individuals } \\
\hline Median ratio & 1.41 & 1.11 & 1.20 & $30.7 \%$ & $-20.9 \%$ & $4.6 \%$ & $23.9 \%$ \\
\hline Median net tax rate & $-3.1 \%$ & $-1.1 \%$ & $-2.1 \%$ & $49.3 \%$ & $-32.4 \%$ & $7.4 \%$ & $37.8 \%$ \\
\hline Share with positive net transfer & $70.7 \%$ & $58.9 \%$ & $62.9 \%$ & $34.1 \%$ & $-32.9 \%$ & $6.6 \%$ & $22.0 \%$ \\
\hline \multicolumn{8}{|l|}{ Only Men } \\
\hline Median ratio & 1.00 & 0.92 & 0.92 & $-0.1 \%$ & NA & NA & NA \\
\hline Median net tax rate & $0.0 \%$ & $0.8 \%$ & $0.8 \%$ & $-2.0 \%$ & NA & NA & NA \\
\hline Share with positive net transfer & $49.9 \%$ & $41.0 \%$ & $41.4 \%$ & $4.6 \%$ & NA & NA & NA \\
\hline \multicolumn{8}{|l|}{ Only Women } \\
\hline Median ratio & 2.55 & 1.35 & 1.86 & $42.7 \%$ & $-8.7 \%$ & $0.9 \%$ & $38.5 \%$ \\
\hline Median net tax rate & $-12.4 \%$ & $-3.6 \%$ & $-9.1 \%$ & $63.2 \%$ & $-12.7 \%$ & $1.0 \%$ & $56.5 \%$ \\
\hline Share with positive net transfer & $88.4 \%$ & $74.8 \%$ & $81.0 \%$ & $45.2 \%$ & $-15.5 \%$ & $0.4 \%$ & $30.0 \%$ \\
\hline
\end{tabular}

Note: "Benefit/tax ratio" is defined as the PV of Social Security benefits divided by PV of payroll taxes paid. Receiving positive transfers" is equivalent to having a negative net tax rate, defined as (PV of SS contributions - PV of SS benefits)/PV of uncapped lifetime earnings. Assumed real interest rate of 2.9 percent.

Source: Authors' calculations based on data from MINT 5 and MINT 6. 
Table 3. Decomposing Changes in Median Lifetime Ratio of Benefits to Contributions, Median Net Tax Rate and Share with Net Transfers: Household Level: DFL Approach

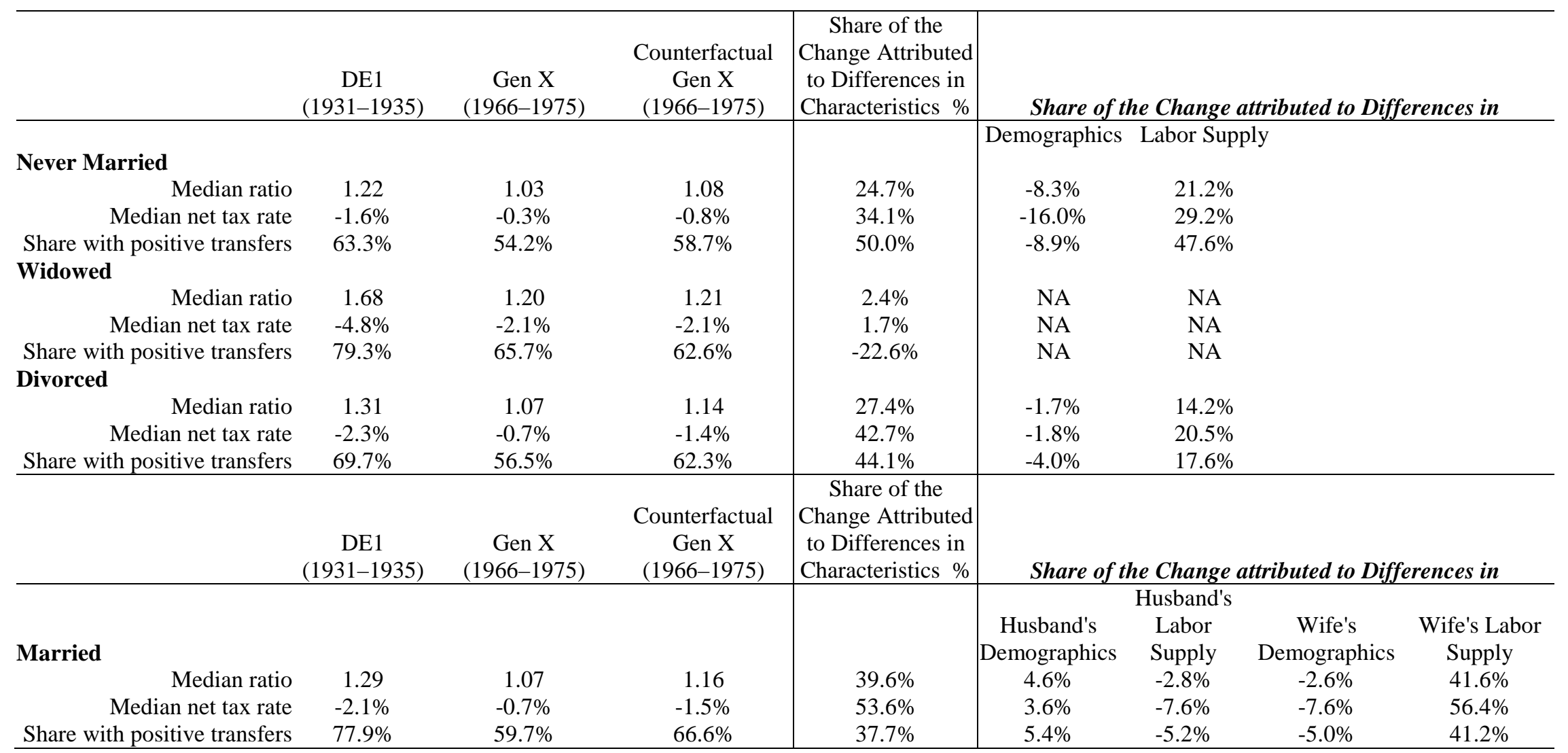

Note: "Benefit/tax ratio" is defined as the PV of Social Security benefits divided by PV of payroll taxes paid. Receiving positive transfers” is equivalent to having a negative net tax rate, defined as (PV of SS contributions - PV of SS benefits)/PV of uncapped lifetime earnings. Assumed real interest rate of 2.9 percent.

Source: Authors' calculations based on data from MINT 5 and MINT 6. 
Table 4. Decomposition of Change in the Share of Individuals Receiving Net Transfers from Social Security, Individual Level: Oaxaca-Blinder Approach

\begin{tabular}{lccc}
\hline & All Individuals & Women Only & Men Only \\
\hline DE1 (1931-1935) & 0.703 & 0.885 & 0.497 \\
Gen X (1966-1975) & 0.586 & 0.747 & 0.408 \\
Difference & 0.117 & 0.138 & 0.089 \\
\hline
\end{tabular}

Difference Due to:

Demographics

Marital Status

Labor Force Activity

Unexplained factors

Percentage Points

Difference Due to:

Demographics

$\begin{array}{rlrlrl}-0.016 & * * * & -0.017 & * * * & -0.067 & \\ 0.006 & * * * & 0.004 & * * * & 0.045 & \\ 0.043 & * * * & 0.081 & * * * & 0.009 & \\ 0.084 & * * * & 0.070 & * * * & 0.102 & * * *\end{array}$

Marital Status

Labor Force Activity

Percentage distribution

Unexplained factors

\begin{tabular}{rrr}
$-14.1 \%$ & $-12.6 \%$ & $-74.6 \%$ \\
$5.5 \%$ & $2.9 \%$ & $50.5 \%$ \\
$36.9 \%$ & $58.5 \%$ & $10.2 \%$ \\
$71.6 \%$ & $51.1 \%$ & $113.9 \%$ \\
\hline
\end{tabular}

Note: Significance: ${ }^{*} \mathrm{p}<0.1,{ }^{* *} \mathrm{p}<0.05$, ${ }^{* * *} \mathrm{p}<0.01$. Receiving positive transfers” is equivalent to having a negative net tax rate, defined as (PV of SS contributions - PV of SS benefits)/PV of uncapped lifetime earnings.

Source: Authors' calculations based on data from MINT 5 and MINT 6. 
Table 5. Decomposition of Change in Share with Net Transfers for Married Couples, OaxacaBlinder Approach

\begin{tabular}{lc}
\hline & Share with net transfers \\
\hline DE1 (1931-1935) & 0.775 \\
Gen X (1966-1975) & 0.593 \\
Difference & 0.182 \\
\hline
\end{tabular}

Difference Due to:

Husband's demographics $\quad-0.009$

Husband's labor force activity $\quad 0.003$

Wife's demographics

Wife's labor force activity

Unexplained factors

Difference Due to:

Husband's demographics

Husband's labor force activity

Wife's demographics

Wife's labor force activity

Unexplained factors

Percentage distribution

Percentage Points

$-0.036^{* * *}$

$0.101^{* * *}$

$0.123 * * *$

Note: Significance: ${ }^{*} \mathrm{p}<0.1,{ }^{* *} \mathrm{p}<0.05,{ }^{* * *} \mathrm{p}<0.01$. Receiving positive transfers” is equivalent to having a negative net tax rate, defined as (PV of SS contributions - PV of SS benefits)/PV of uncapped lifetime earnings.

Source: Authors' calculations based on data from MINT 5 and MINT 6.

Table 6. Individual and Household Median Benefit/Tax Ratio under Alternative Discount Rate Assumptions

\begin{tabular}{lrrrrrrrr}
\hline & \multicolumn{3}{c}{ Individual Level } & & \multicolumn{3}{c}{ Household Level } \\
\cline { 2 - 3 } & 2 \% real & Baseline & T-bill rate & & 2 \% real & Baseline & T-bill rate \\
\hline DE1 (1931-1935) & 1.82 & 1.41 & 1.36 & & 1.75 & 1.36 & 1.32 \\
DE2 (1936-1941) & 1.86 & 1.42 & 1.40 & & 1.77 & 1.35 & 1.33 \\
War baby (1942- & & & & & & & \\
1947) & 1.61 & 1.21 & 1.22 & & 1.55 & 1.17 & 1.18 \\
EBB (1948-1953) & 1.56 & 1.16 & 1.16 & & 1.49 & 1.11 & 1.11 \\
MBB (1954-1959) & 1.51 & 1.13 & 1.13 & & 1.45 & 1.08 & 1.08 \\
LBB (1960-1965) & 1.45 & 1.09 & 1.09 & & 1.42 & 1.06 & 1.07 \\
Gen X(1966-1975) & 1.48 & 1.11 & 1.11 & & 1.43 & 1.07 & 1.08 \\
\hline
\end{tabular}

Note: "Benefit/tax ratio" is defined as the PV of Social Security benefits divided by PV of payroll taxes paid. Assumed real interest rate under baseline is 2.9 percent. T-bill discount scenario assumes historic real 10-year T-bill rate till 2011 and a 3 percent real rate after 2011.

Source: Authors' calculations based on MINT 5 and MINT 6. 
Table 7. Characteristics of individuals when first claiming Social Security benefits, by HRS birth cohort

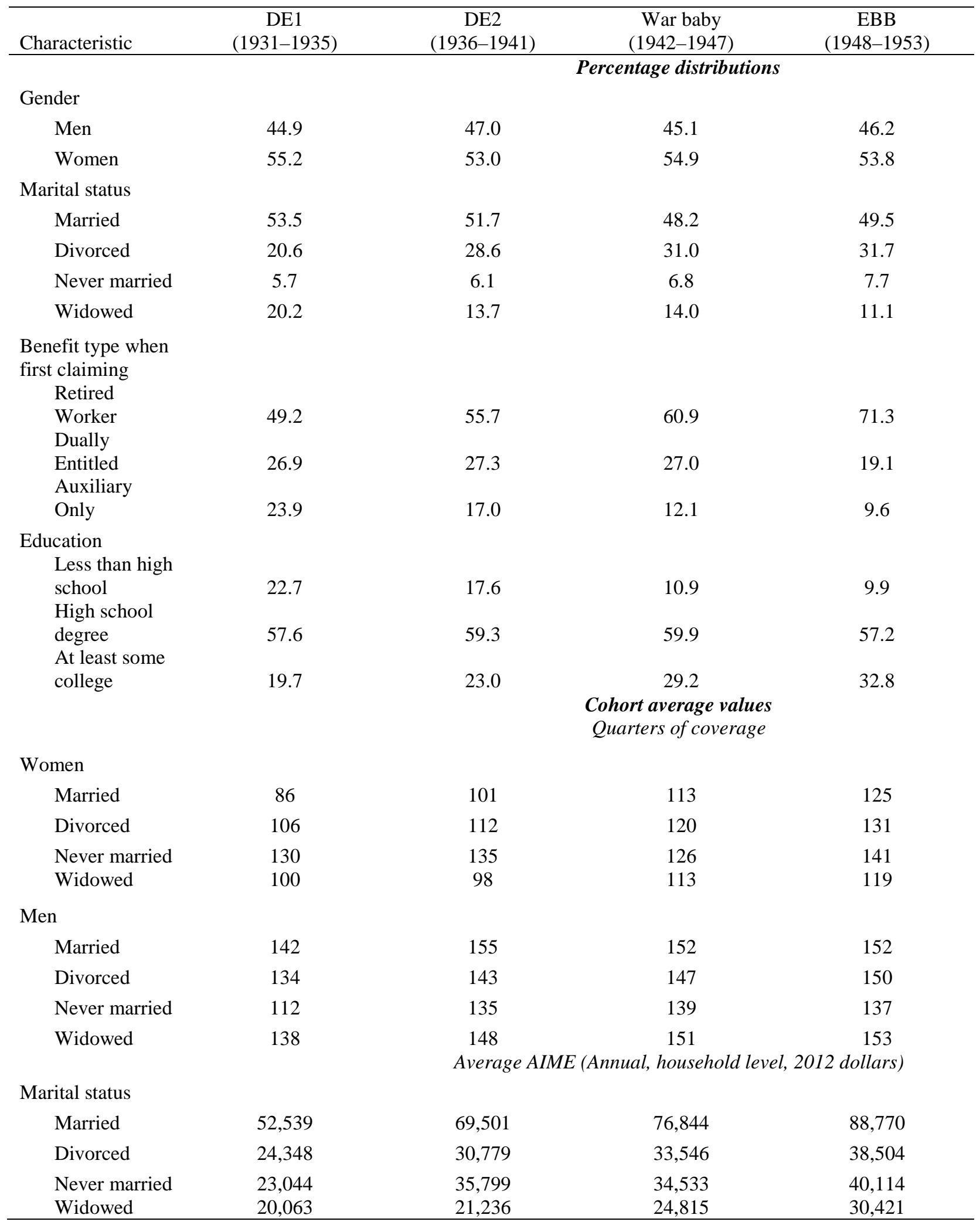

Source: Authors' calculations based on the HRS. 
Table 8. Individual Median Ratio of Social Security Benefit to Social Security Tax, by Marital Status and HRS Birth Cohort

\begin{tabular}{lcccc}
\hline Marital status and birth cohort & DE1 & DE2 & War baby & EBB \\
$(1931-1935)$ & $(1936-1941)$ & $(1942-1947)$ & $(1948-1953)$ \\
\hline Never married & 1.18 & 1.07 & 0.90 & 0.79 \\
Currently married & 1.38 & 1.11 & 0.94 & 0.84 \\
Widowed & 1.77 & 1.83 & 1.56 & 1.17 \\
Divorced & 1.30 & 1.22 & 0.99 & 0.91 \\
All & 1.39 & 1.15 & 0.98 & 0.87 \\
\hline
\end{tabular}

Source: Authors' calculations based on the HRS. 
Table 9. Individual Median Ratio of Social Security Benefit to Social Security Tax, by Sex, Marital Status, and HRS Birth Cohort

\begin{tabular}{lcccc}
\hline Gender, marital status and birth cohort & DE1 & DE2 & War baby & EBB \\
$(1931-1935)$ & $(1936-1941)$ & $(1942-1947)$ & $(1948-1953)$ \\
\hline Never married & & & & \\
$\quad$ Men & 1.18 & 1.04 & 0.81 & 0.74 \\
$\quad$ Women & 1.17 & 1.10 & 0.99 & 0.87 \\
Currently married & & & & \\
$\quad$ Men & 1.11 & 0.93 & 0.76 & 0.66 \\
$\quad$ Women & 2.21 & 1.60 & 1.34 & 1.09 \\
Widowed & & & & \\
$\quad$ Men & 1.01 & 0.86 & 0.73 & 0.69 \\
$\quad$ Women & 2.24 & 2.38 & 1.99 & 1.28 \\
Divorced & & & & \\
$\quad$ Men & 1.02 & 0.93 & 0.76 & 0.71 \\
$\quad$ Women & 1.61 & 1.49 & 1.22 & 1.06 \\
All & & & & \\
$\quad$ Men & 1.10 & 0.93 & 0.76 & 0.68 \\
$\quad$ Women & 1.99 & 1.61 & 1.30 & 1.09 \\
\hline
\end{tabular}

Source: Authors' calculations based on the HRS.

Table 10. Household Median Ratio of Social Security Benefit to Social Security Tax, by Marital Status and HRS Birth Cohort

\begin{tabular}{lcccc}
\hline Marital status and birth cohort & DE1 & DE2 & War baby & EBB \\
Never married & 1.18 & 1.07 & 0.90 & 0.79 \\
Currently married & 1.35 & 1.11 & 0.92 & 0.80 \\
Widowed & 1.54 & 1.53 & 1.31 & 1.11 \\
Divorced & 1.21 & 1.11 & 0.93 & 0.84 \\
All & 1.35 & 1.12 & 0.94 & 0.82 \\
\hline
\end{tabular}

Source: Authors' calculations based on the HRS. 


\section{RECENT WORKING PAPERS FROM THE CENTER FOR RETIREMENT RESEARCH AT BOSTON COLLEGE}

Sources of Increasing Differential Mortality Among the Aged by Socioeconomic Status Barry P. Bosworth, Gary Burtless, and Kan Zhang, June 2015

Do Retired Americans Annuitize Too Little? Trends in the Share of Annuitized Income Barry P. Bosworth, Gary Burtless, and Mattan Alalouf, June 2015

Impact of the Financial Crisis on Long-Term Growth Barry P. Bosworth, June 2015

Post-War Trends in Labor Income in the Social Security Earnings Records Gary Burtless and Kan Zhang, June 2015

Improving Employees' Life and Disability Insurance Benefit Decisions: Results of an Employer Survey

Anek Belbase, Norma B. Coe, and Matthew S. Rutledge, June 2015

Overcoming Barriers to Life Insurance Coverage: A Behavioral Approach Anek Belbase, Norma B. Coe, and April Yanyuan Wu, June 2015

How Do People Decide on Life Insurance and Long-Term Disability Insurance Coverage? Norma B. Coe and Anek Belbase, June 2015

What Do Subjective Assessments of Financial Well-Being Reflect?

Steven A. Sass, Anek Belbase, Thomas Cooperrider, and Jorge D. Ramos-Mercado, March 2015

The Impact of Leakages from 401(k)s and IRAs

Alicia H. Munnell and Anthony Webb, February 2015

Recruiting and Retaining High-Quality State and Local Workers: Do Pensions Matter? Alicia H. Munnell, Jean-Pierre Aubry, and Geoffrey T. Sanzenbacher, January 2015

Do Tax Incentives Increase 401(k) Retirement Saving? Evidence from the Adoption of Catch-Up Contributions

Matthew S. Rutledge, April Yanyuan Wu, and Francis M. Vitagliano, November 2014

Are Retirees Falling Short? Reconciling the Conflicting Evidence

Alicia H. Munnell, Matthew S. Rutledge, and Anthony Webb, November 2014

All working papers are available on the Center for Retirement Research website (http://crr.bc.edu) and can be requested by e-mail (crr@bc.edu) or phone (617-552-1762). 